Supporting information for the manuscript entitled

\title{
A novel cyclic mobile transporter can induce apoptosis by facilitating chloride anion transport into cells
}

Goutam Kulsi ${ }^{1,2 \ddagger}$, Achinta Sannigrahi ${ }^{1 \ddagger}$, Snehasis Mishra ${ }^{3,4}$, Krishna Das Saha ${ }^{3}$, Sriparna Datta $^{4}$, Partha Chattopadhyay ${ }^{2}$, Krishnananda Chattopadhyay*1

\footnotetext{
${ }^{1}$ Structural Biology and Bioinformatics Division, CSIR-Indian Institute of Chemical Biology (IICB), Kolkata - 700032, India.

${ }^{2}$ Organic and Medicinal Chemistry Division, CSIR-Indian Institute of Chemical Biology (IICB), Kolkata - 700032, India.

${ }^{3}$ Cancer Biology and Inflammatory Disorder Division, CSIR-Indian Institute of Chemical Biology (IICB), Kolkata - 700032, India.

${ }^{4}$ Department of Chemical Technology, University of Calcutta, Kolkata-700009,India Corresponding author email: krish@iicb.res.in

$¥$ contributed equally
}

\section{Table of contents}

3. Liposome preparation and characterization

4. FT-IR investigation on lipid bilayer

5. Preparation and Characterization of Compounds 


\section{General Experimental Details:}

\section{Synthetic Details}

Solvents were dried over standard drying agents and freshly distilled prior to use. IR spectra between 400 and $4000 \mathrm{~cm}^{-1}$ were recorded with an FT-IR spectrometer using $\mathrm{KBr}$ pellets. Mass spectra were obtained under high resolution (HRMS). ${ }^{1} \mathrm{H}$ and ${ }^{13} \mathrm{C}$ NMR spectra were recorded in deuterated solvents on BrukerAvance $(300 \mathrm{MHz})$ and Bruker $(600 \mathrm{MHz})$ spectrometers. ${ }^{1} \mathrm{H}$ NMR multiplicity patterns are designated as singlet (s), doublet (d), triplet(t), or quartet (q); all first order splitting patterns are assigned. Splitting patterns that could not be interpreted or easily visualized are designated as multiplet (m) or broad (br). Column chromatographic separations were carried out on silica gel (60-120 mesh) and the cyclic peptide 1 and 2 was purified by preparative HPLC on Shimadzu UFLC (Model:LC20AD) ODS-3-V, 250×4.6 mm, $5 \mu \mathrm{m}(\mathrm{C}-18 / \mathrm{AR} / 25)$ with methanol:water (45:55) as mobile

phase. 1-Hydroxybenzotriazole (HOBt) and 1-[3-(dimethylamino)propyl]-3-ethylcarbodiimide hydrochloride (EDCI) were purchased from Spectrochem. All other reagents and solvents were purchased from Sigma-Aldrich or Merck. 
2. General Synthetic Scheme:

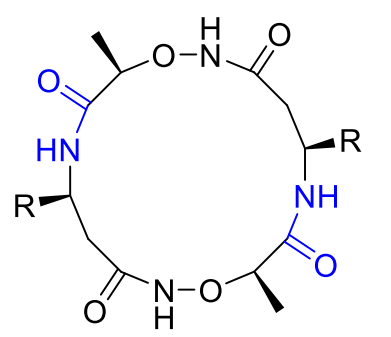

macrocyclic amide/aminoxy oligomer $\mathrm{R}=$ sugar

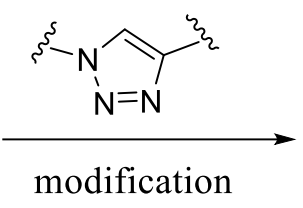

modification

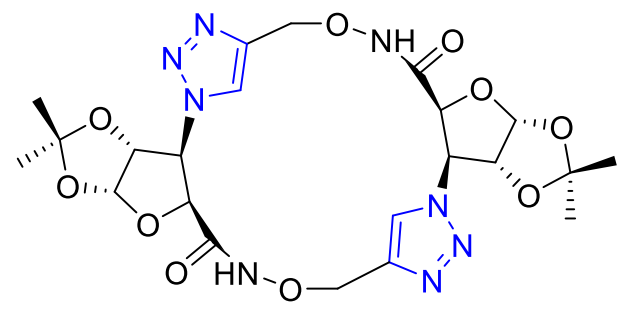

10

triazole/aminoxy based cyclic oligomer

Scheme S1: (1,4)-Linked triazole modification of aminoxy amide based cyclic anion transporter. 


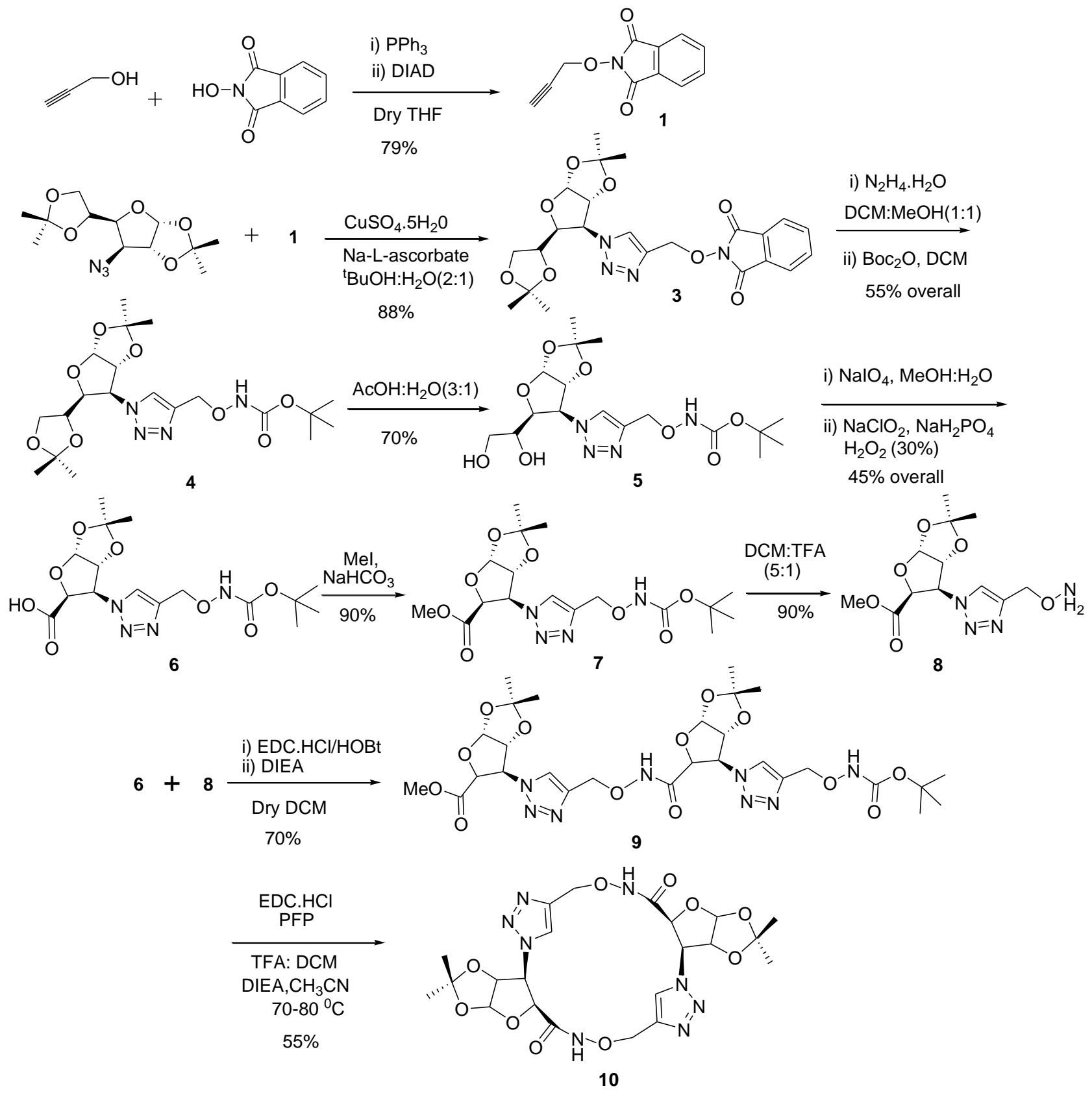

Scheme S2: Synthesis of triazole/aminoxy amide based cyclic anion transporter 10. 


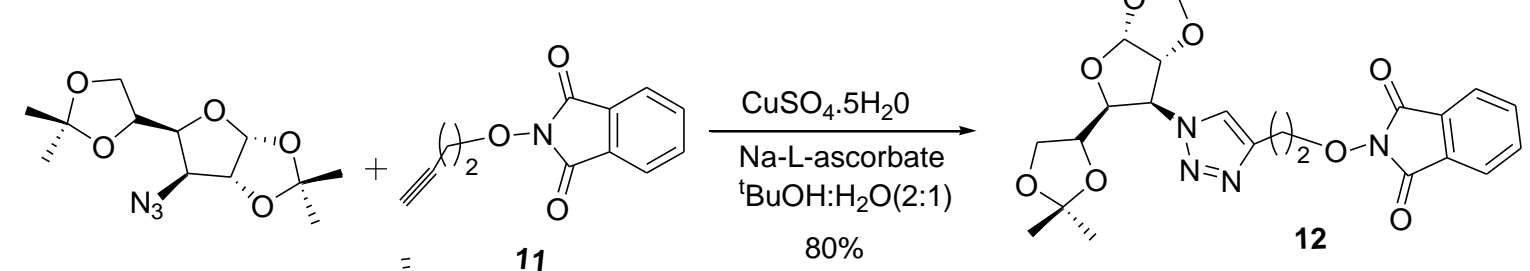

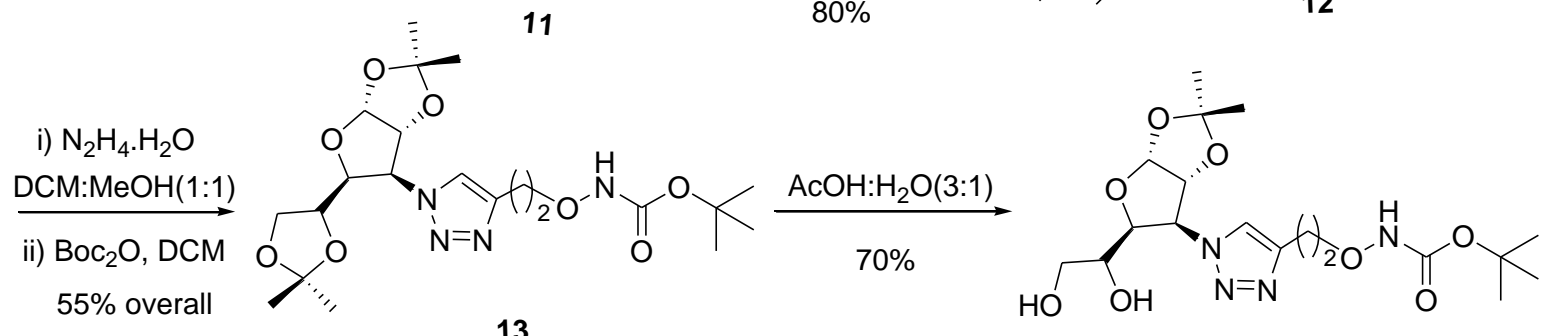
13

i) $\mathrm{NaIO}_{4}, \mathrm{MeOH}: \mathrm{H}_{2} \mathrm{O}$

ii) $\mathrm{NaClO}_{2}, \mathrm{NaH}_{2} \mathrm{PO}_{4}$ $\mathrm{H}_{2} \mathrm{O}_{2}(30 \%)$ $45 \%$<smiles></smiles><smiles>COC(=O)C1OC2OC(C)(C)OC2C1n1cc(C=CONC(=O)OC(C)(C)C)nn1</smiles>
16

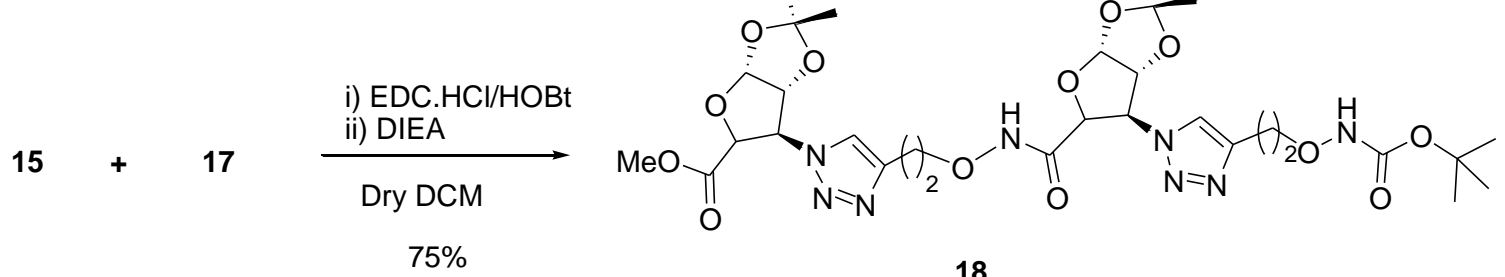

Scheme S3: Synthesis of triazole/aminoxy amide based acyclic anion transporter 18. 
3. Liposome preparation, characterization

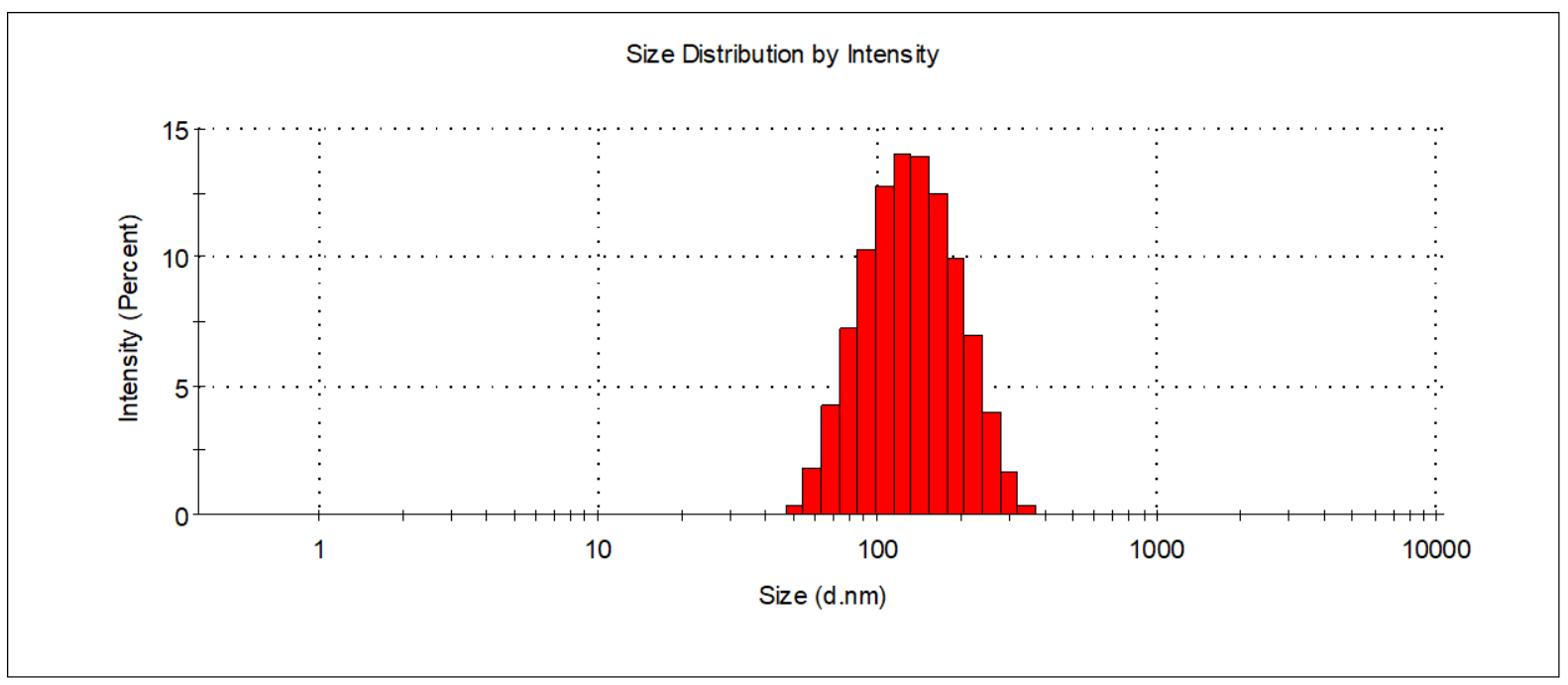

Figure S1: Size determination of as prepared Large Unilamellar Vesicles (LUV) composed of Egg-PC. 
4. Effect of compound 10 and 18 on the lipid bilayer by FT-IR investigation:
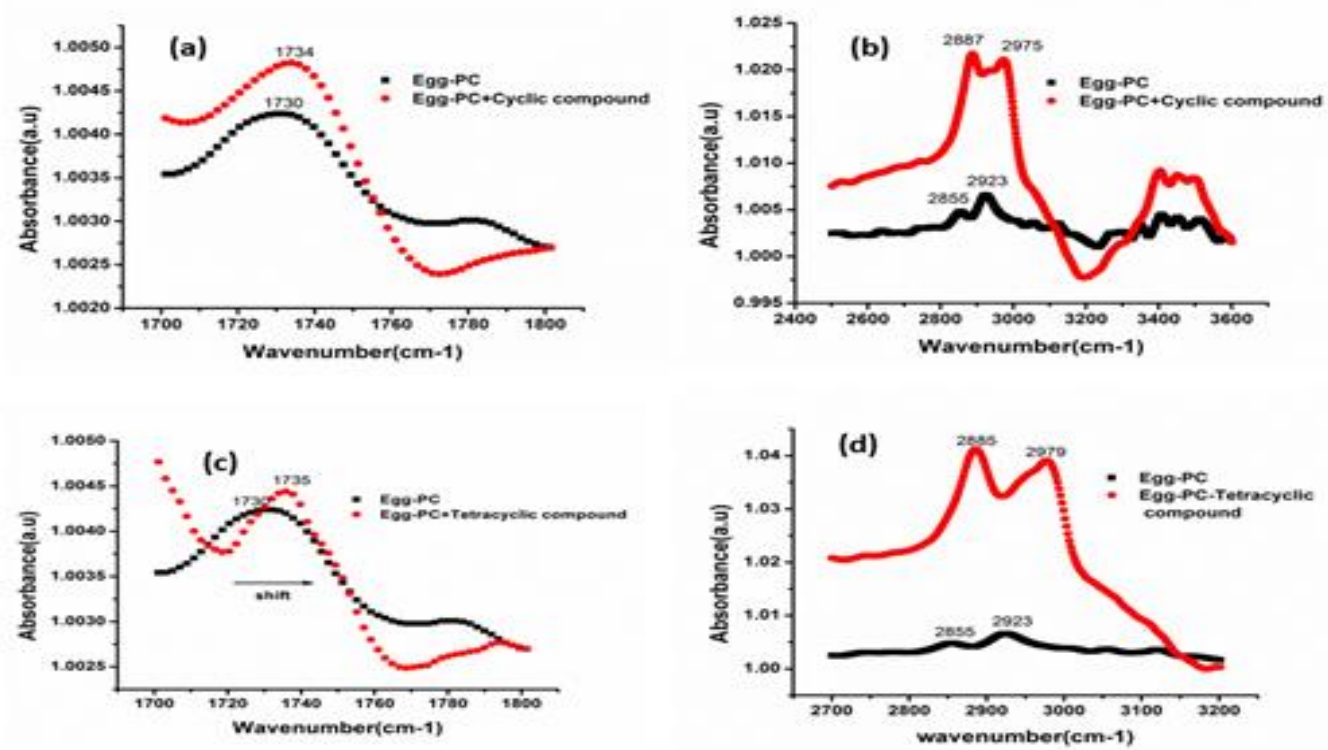

Figure S2: (a) FTIR spectral signatures of Egg-PC for $\mathrm{C}=\mathrm{O}$ vibrational frequency in presence (red) and absence (black) of cyclic compound 10, (b) Symmetric $\mathrm{CH}_{2}$ vibrational frequency alterations due to interaction of membrane's hydrocarbon residue with cyclic compound 10 ; (c) $\mathrm{C}=\mathrm{O}$ vibrational changes of Egg-PC upon interaction with acyclic compound 18 and (d) symmetric $\mathrm{CH}_{2}$ vibrational frequency alterations due to interaction of membrane's hydrocarbon residue with tetracyclic compound 18. 


\section{Preparation and Characterization of Compounds:}

\section{Synthesis of O-phthalimide protected propargyl alcohol (1)}

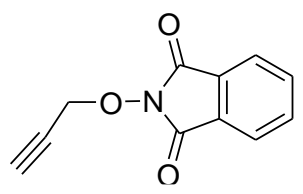

\section{Compound 1}

Propargyl alcohol (250 mg, $3.8 \mathrm{mmol}), N$-hydroxyphthalimide (1091 mg, $6.6 \mathrm{mmol})$ and triphenylphoshphine (1075mg, $4.1 \mathrm{mmol}$ ) were dissolved dry THF. To the reaction mixture diisopropylazodicarboxylate, i.e.DIAD $(1032 \mathrm{mg}, 5.1 \mathrm{mmol})$ was added at $0{ }^{0} \mathrm{C}$ and stirred overnight. After the completion of reaction by checking TLC, the solvent was removed in high vacuum and the residue purified by column chromatography using PE:EA (3:1) as eluent to afford the $O$-phthalimide protected propargyl1 alcoholas white solid (79\%).

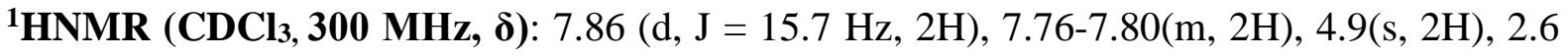
(s, 1H). ${ }^{13} \mathbf{C ~ N M R ~ ( C D C l 3 , ~} 75$ MHz, o): 163.3, 134.6, 128.9, 64.9, 123.7, 78.2, 76.4. HRMS $(\mathbf{M + N a})^{+}$Calculated for $\mathrm{C}_{11} \mathrm{H}_{7} \mathrm{NO}_{3} \mathrm{Na}$ : 224.0324, Found: 224.0318 .

\section{Synthesis of click compound (3)}

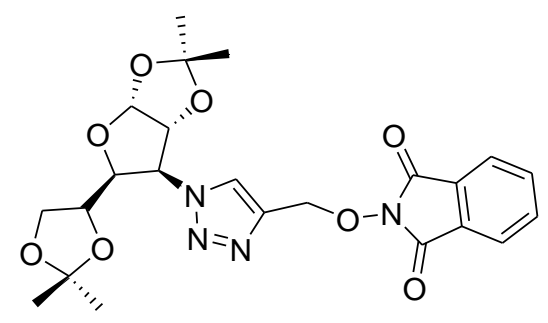

\section{Compound 3}

$O$-phthalimide protected propargyl alcohol $\mathbf{1}(450 \mathrm{mg}, 2.23 \mathrm{mmol})$ and sugar azide2(320mg, $1.12 \mathrm{mmol}$ ) were taken in $250 \mathrm{ml} \mathrm{RB}$ with a mixture of tert. butanol and water $(2: 1)$ as the solvent. To the reaction mixture sodiumL-ascorbate $(320 \mathrm{mg}, 1.61 \mathrm{mmol})$ and copper sulphate $(400 \mathrm{mg}, 1.6 \mathrm{mmol})$ were added and stirred overnight. After the completion of reaction as determined by checking TLC, the reaction mixture was washed with brine and extracted with DCM $(3 \times 30 \mathrm{~mL})$. The combined organic layers were dried over $\mathrm{Na}_{2} \mathrm{SO}_{4}$ and further purified bycolumn chromatographywith PE:EA (1:1) as eluent to afford the product 3 as white solid (88\%). 
${ }^{1}$ HNMR (CDCl 3,300 MHz, $)$ ): 7.99 (s, 1H), 7.72-7.81 (m, 4H), 6.21(d, J = 3.6 Hz, 1H), 5.37 $(\mathrm{m}, 2 \mathrm{H}), 5.15(\mathrm{~d}, \mathrm{~J}=3.3 \mathrm{~Hz}, 1 \mathrm{H}), 5.05(\mathrm{~d}, \mathrm{~J}=3.6 \mathrm{~Hz}, 1 \mathrm{H}), 4.33(\mathrm{dd}, \mathrm{J}=9.3,3.6 \mathrm{~Hz}, 1 \mathrm{H}), 3.95-$ $3.99(\mathrm{~m}, 2 \mathrm{H}), 3.22(\mathrm{~m}, 1 \mathrm{H}) 1.46(\mathrm{~s}, 3 \mathrm{H}), 1.37(\mathrm{~s}, 3 \mathrm{H}), 1.28(\mathrm{~s}, 6 \mathrm{H}) ;{ }^{13} \mathbf{C}$ NMR $\left(\mathbf{C D C l}_{3}, 75\right.$ MHz, $\delta): 163.3, \quad 134.4, \quad 142.2, \quad 128.8, \quad 126.4, \quad 123.5, \quad 112.5$, 109.8, 106.2,83.4,80.5,72.1,70.2,67.5,65.9,26.9,26.7,26.2,24.9. $\quad$ HRMS $\quad(\mathbf{M + N a})^{+}$ Calculatedfor $\mathrm{C}_{23} \mathrm{H}_{26} \mathrm{~N}_{4} \mathrm{O}_{8} \mathrm{Na}$ : 509.1648, Found: 509.1656.

\section{Synthesis of Boc protected click compound (5)}

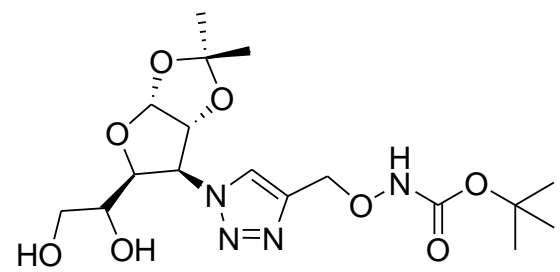

\section{Compound 5}

Compound 3 (500 mg, $1.02 \mathrm{mmol}$ ) was dissolved in dry MeOH and DCM (1:1), hydrazine monohydrate $(0.15 \mathrm{~mL}, 3.08 \mathrm{mmol})$ was added and stirred for $2 \mathrm{hr}$. After the completion of reaction by checking TLC, solvent was evaporated and extracted with DCM and $5 \% \mathrm{NaHCO}_{3}$, washed with brine. The combined organic layers were dried over $\mathrm{Na}_{2} \mathrm{SO}_{4}$ and evaporated to get the crude aminoxy compound as $\mathbf{5}$, which was used directly for Boc protection.

To the solution of amine in dry DCM, Boc anhydride $(0.5 \mathrm{~mL}, 2.04 \mathrm{mmol})$ was added. The reaction mixture was stirred for $4 \mathrm{hr}$. After the completion of reaction (TLC control) solvent was evaporated to get the crude product which was purified by column chromatography employing PE:EA(1:1) to obtain compound $\mathbf{4}$ as white solid (55\% over two steps).Compound 4 was treated with $\mathrm{AcOH}: \mathrm{H}_{2} \mathrm{O}(3: 1)$ and the reaction mixture was stirred overnight at RT. After completion of the reaction by checking TLC, the mixture was evaporated in a rotary evaporator and purified by column chromatography PE:EA (1:2) to get $\mathbf{5}$ as white solid $(70 \%)$.

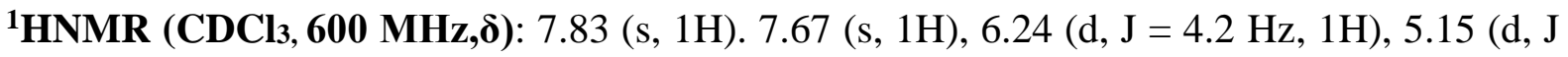
$=3.6 \mathrm{~Hz}, 1 \mathrm{H}), 5.10(\mathrm{~d}, \mathrm{~J}=3.6 \mathrm{~Hz}, 1 \mathrm{H}), 4.98(\mathrm{~m}, 2 \mathrm{H}), 4.45(\mathrm{dd}, \mathrm{J}=9.6,3.6 \mathrm{~Hz}, 1 \mathrm{H}), 3.74(\mathrm{dd}$, $\mathrm{J}=11.4,3.0 \mathrm{~Hz}, 1 \mathrm{H}), 3.36(\mathrm{~m}, 1 \mathrm{H}), 2.76(\mathrm{~m}, 1 \mathrm{H}) 1.58(\mathrm{~s}, 3 \mathrm{H}), 1.45(\mathrm{~s}, 9 \mathrm{H}), 1.37(\mathrm{~s}, 3 \mathrm{H}) .{ }^{\mathbf{1 3}} \mathbf{C}$

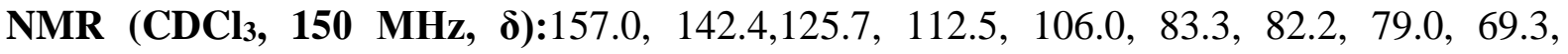
68.7,65.9, 64.2, 28.1, 26.6, 26.1. HRMS (M+Na) ${ }^{+}$Calculatedfor $\mathrm{C}_{17} \mathrm{H}_{28} \mathrm{~N}_{4} \mathrm{O}_{8} \mathrm{Na}: 439.1805$, Found: 439.1798. 


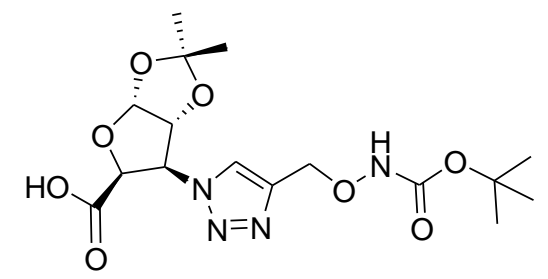

\section{Compound 6}

The diol 5 was dissolved in $\mathrm{MeOH}$ and sodium periodate $\left(200 \mathrm{mg}\right.$ ) was added at $0^{\circ} \mathrm{C}$ to afford the aldehyde. After $5 \mathrm{hr}$, the reaction mixture was filtered, $\mathrm{MeOH}$ was evaporated, and the aqueous part was extracted with EtOAc $(3 \times 25 \mathrm{~mL})$. The combined organic layer was dried over $\mathrm{Na}_{2} \mathrm{SO}_{4}$ and evaporated to furnish the aldehyde as colorless oil which was used for the next step without further purification.To the stirred solution of above obtained aldehyde in acetonitrile, sodium chlorite (240mg) and sodium hydrogen phosphate (300 mg) were added. After $5 \mathrm{~min}, 0.4 \mathrm{~mL}$ hydrogen peroxide was added and the reaction mixture was stirred overnight at RT. Then the solvent was evaporated and the residue extracted with 5\% $\mathrm{NaHCO}_{3}$ and ethyl acetate. EtOAc part was discarded; the aqueous layer was acidified by using sodium bisulphate, and then extracted by ethyl acetate $(3 \times 30 \mathrm{~mL})$. The combined organic extract was dried over $\mathrm{Na}_{2} \mathrm{SO}_{4}$ and evaporated to get the acid 6 (overall yield $45 \%$ ).

\section{Synthesis of Boc protected ester compound (7):}

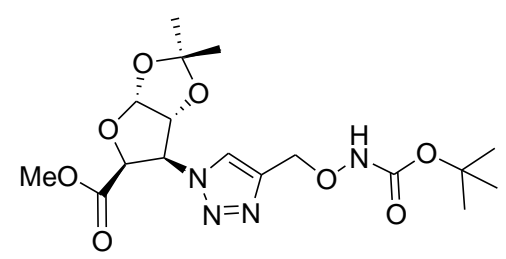

\section{Compound 7}

To a solution of acid $6(100 \mathrm{mg}, 0.23 \mathrm{mmol})$ in dimethyl formamide, $\mathrm{NaHCO}_{3}$ (40 mg, 0.46 $\mathrm{mmol})$ and iodomethane $(0.03 \mathrm{~mL}, 0.46 \mathrm{mmol})$ were added. The reaction was stirred for $4 \mathrm{hr}$. EtOAc was added to the reaction mixture which was washed with aqueous $\mathrm{Na}_{2} \mathrm{~S}_{2} \mathrm{O}_{3}$ solution $(2 \times 15 \mathrm{~mL})$ and brine $(1 \times 15 \mathrm{~mL})$. The organic layer was dried over $\mathrm{Na}_{2} \mathrm{SO}_{4}$ and evaporated under reduced pressure to give the pure methyl ester $\mathbf{7}$ as colourless liquid (90\%). 


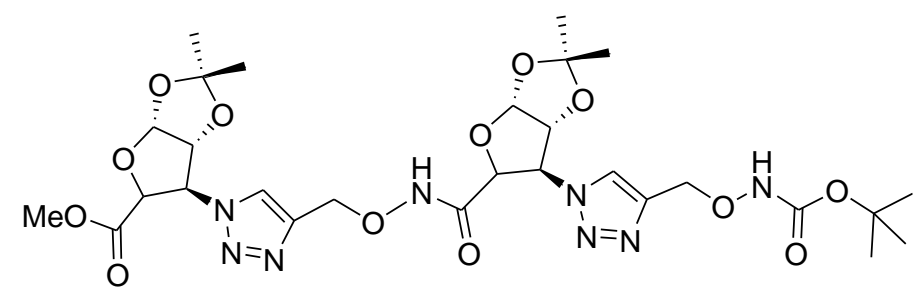

\section{Compound 9}

Compound 7 (500 mg, $1.02 \mathrm{mmol}$ ) was dissolved in dry DCM:TFA (5:1) and stirred for $2 \mathrm{hr}$. After the completion of reaction by checking TLC, solvent was evaporated to get crude the amine $\mathbf{8}$ which was directly used for the coupling reaction.

To a stirred solution of compound $6(140 \mathrm{mg}, 0.35 \mathrm{mmol})$ in dry DCM, HOBt (47 $\mathrm{mg}, 0.30$ mmol) and $\mathrm{EDC} . \mathrm{HCl}(66 \mathrm{mg}, 0.34 \mathrm{mmol})$ were added at $0{ }^{0} \mathrm{C}$. After stirring at $0{ }^{0} \mathrm{C}$ for $1 \mathrm{hr}$, the amine $8(124 \mathrm{mg}, 0.21 \mathrm{mmol})$ was added and stirred overnight under $\mathrm{N}_{2}$ atmosphere. After completion of the reaction by checking TLC, the reaction mixture was diluted with DCM and washed with $1(\mathrm{~N}) \mathrm{HCl}, 5 \%$ aq. $\mathrm{NaHCO}_{3}$ and finally with brine and dried over $\mathrm{Na}_{2} \mathrm{SO}_{4}$. The organic layer was concentrated to give a solid which was purified by column chromatography using $8 \% \mathrm{MeOH}$ in DCM as eluent to afford the tetramer 9 as white solid (70\%).

${ }^{1}$ HNMR (CDCl3, 600 MHz, $\delta$ ): 8.73 (s, 1H). 7.89 (s, 1H), 7.69 (s, 1H), 7.61 (s, 1H), 6.58 (d, J $=4.2 \mathrm{~Hz}, 1 \mathrm{H}), 6.33(\mathrm{~d}, \mathrm{~J}=4.2 \mathrm{~Hz}, 1 \mathrm{H}), 5.45(\mathrm{~d}, \mathrm{~J}=4.2 \mathrm{~Hz}, 1 \mathrm{H}), 5.28(\mathrm{~d}, \mathrm{~J}=4.2 \mathrm{~Hz}, 1 \mathrm{H})$, $5.12(\mathrm{~m}, 2 \mathrm{H}), 5.09(\mathrm{~m}, 1 \mathrm{H}), 4.97(\mathrm{~m}, 3 \mathrm{H}), 4.77(\mathrm{~d}, \mathrm{~J}=13.2 \mathrm{~Hz}, 1 \mathrm{H}), 4.45(\mathrm{~d}, \mathrm{~J}=13.2 \mathrm{~Hz}$, $1 \mathrm{H}), 3.57(\mathrm{~s}, 3 \mathrm{H}), 1.60(\mathrm{~s}, 3 \mathrm{H}), 1.56(\mathrm{~s}, 3 \mathrm{H}), 1.47(\mathrm{~s}, 9 \mathrm{H}), 1.43(\mathrm{~s}, 3 \mathrm{H}), 1.38(\mathrm{~s}, 3 \mathrm{H}) .{ }^{13} \mathrm{C}$ NMR (CDCl3, 150 MHz, $)$ ):166.8, 163.6, 156.9, 142.7, 142.0, 125.8, 124.3, 122.8, 113.5, 113.1, 106.8, 106.0, 105.8,83.4, 82.8, 81.7, 80.0, 78.5, 78.0, 69.1, 68.7,66.5, 65.7, 52.7, 28.1, 26.8, 26.6, 26.2. HRMS: $(\mathrm{M}+\mathrm{Na})^{+}$: calculated for $\mathrm{C}_{28} \mathrm{H}_{40} \mathrm{~N}_{8} \mathrm{O}_{13} \mathrm{Na}: 719.2613$; found:719.2620. 


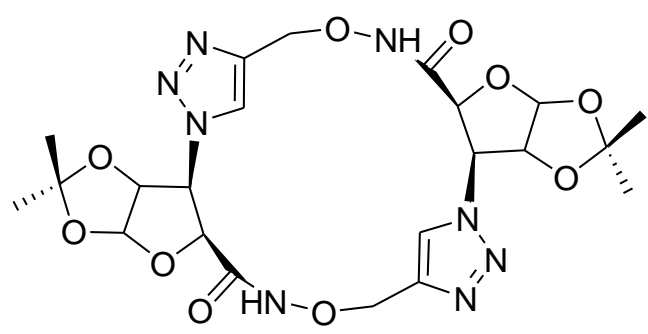

\section{Compound 10}

To a stirred solution of compound $9(60 \mathrm{mg}, 0.08 \mathrm{mmol})$ in $15 \mathrm{~mL}$ THF: $\mathrm{H}_{2} \mathrm{O}(3: 1)$ at $0^{0} \mathrm{C}$, LiOH. $\mathrm{H}_{2} \mathrm{O}(13.2 \mathrm{mg}, 0.31 \mathrm{mmol})$ was added and stirred for $1 \mathrm{hr}$. The reaction mixture was acidified with aqueous sodium bisulphate solution and extracted with ethyl acetate $(6 \times 10$ $\mathrm{mL}$ ). The combined organic layer was dried over $\mathrm{Na}_{2} \mathrm{SO}_{4}$ and concentrated under reduced pressure to furnish the corresponding acid as white semi solid (95\%).

To a stirred solution of Boc tetramer acid (40 mg, $0.05 \mathrm{mmol}$ ) in dry $\mathrm{CH}_{2} \mathrm{Cl}_{2}$, EDC. $\mathrm{HCl}$ (6 $\mathrm{mg}, 0.03 \mathrm{mmol}$ ) was added at $0^{\circ} \mathrm{C}$. After stirring at $0^{\circ} \mathrm{C}$ for $10 \mathrm{~min}$,pentafluoro phenol (1 to 2 drops) was introduced to the reaction mixture and stirred overnight at room temperature under $\mathrm{N}_{2}$. After completion of the reaction by checking TLC, it was diluted with DCM andwashed with $1(\mathrm{~N}) \mathrm{HCl}(1 \times 25 \mathrm{~mL})$ and saturated $\mathrm{NaCl}$ solution $(1 \times 20 \mathrm{~mL})$, and dried over $\mathrm{Na}_{2} \mathrm{SO}_{4}$. After evaporating the solvent, the residue was washed with n-hexane four times to furnish the tetramericBoc-pentaflourophenyl ester $(85 \%)$ which was treated with TFA:DCM(1:5) at $0^{0} \mathrm{C}$ for $1 \mathrm{hr}$ then at RT for another $1 \mathrm{hr}$. After completion of the reaction, the solvent was evaporated, $0.4 \mathrm{~mL}$ dry DIEA was added to the reaction mixture, and then cyclized in dry acetonitrile solvent at $70-80{ }^{\circ} \mathrm{C}$ for 3 to $4 \mathrm{hr}$. After the completion of reaction (TLC), the reaction mixture was extracted with EtOAc $(3 \times 5 \mathrm{~mL})$; the combined extracts were dried over $\mathrm{Na}_{2} \mathrm{SO}_{4}$ and concentrated under reduced pressure to afford the crude cyclic peptide $\mathbf{1 0}$ which was purified by RP-HPLC $\left(\mathrm{C} 18\right.$ column/ $\left.\mathrm{CH}_{3} \mathrm{CN} / \mathrm{H}_{2} \mathrm{O}\right)$.

${ }^{1}$ HNMR (CDCl3, 600 MHz, $)$ ): 9.52 (s,1H), 7.79 (s,1H), 6.46 (d, J = 3.6 Hz, 1H), 5.28 (d, J = $3.6 \mathrm{~Hz}, 1 \mathrm{H}), 5.24(\mathrm{~d}, \mathrm{~J}=4.2 \mathrm{~Hz}, 1 \mathrm{H}), 5.10(\mathrm{~d}, \mathrm{~J}=4.2 \mathrm{~Hz}, 1 \mathrm{H}), 4.75(\mathrm{~d}, \mathrm{~J}=11.2 \mathrm{~Hz}, 1 \mathrm{H}), 4.50$ $(\mathrm{d}, \mathrm{J}=11.2 \mathrm{~Hz}, 1 \mathrm{H}), 1.39$ (s,1H),1.25 (s,1H). ${ }^{\mathbf{1 3}} \mathbf{C}$ NMR (CDCl3, $\left.150 \mathbf{~ M H z , ~} \boldsymbol{\delta}\right): 163.1,143.8$, $123.5,113.4,106.4,83.2,79.5,65.6,26.8,26.2,22.6$. 
HRMS (M+Na) ${ }^{+}$Calculatedfor $\mathrm{C}_{22} \mathrm{H}_{28} \mathrm{~N}_{8} \mathrm{O}_{10} \mathrm{Na}: 587.1826$, Found: 587.1820.FT - IR (neat, 298K, $\mathbf{c m}^{-1}$ ): 1689, 1707, 2114, 2268, 2899, 2932, 3281, 3325.

Synthesis of O-phthalimide protected homo propargyl alcohol (11):

Synthetic procedure is similar to compound 10; Yield (85\%).

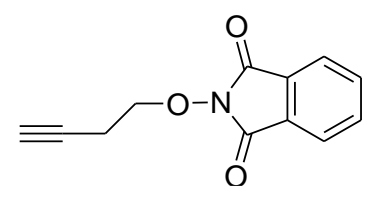

\section{Compound 11}

${ }^{1}$ HNMR (CDCl3, 300 MHz, $)$ ): 7.84 (m, 2H). 7.76 (m, 2H), 4.33 (m, 2H), 2.73 (m, 2H), 1.99 (s, 1H); 13C NMR (CDCl3, 75 MHz, o):163.4, 134.5, 128.8, 123.6, 79.1, 75.5, 70.2, 18.7. HRMS (M+Na)+ Calculated for $\mathrm{C}_{12} \mathrm{H}_{9} \mathrm{NO}_{3} \mathrm{Na}: 238.0480$, Found: 238.0488 .

Synthesis of click product (12):

Synthetic procedure is similar to compound 10; Yield (80\%)

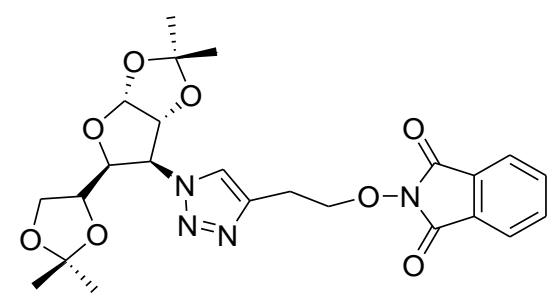

\section{Compound 12}

${ }^{1}$ HNMR (CDCl3, 300 MHz, $)$ ):7.96 (s,1H), 7.86-7.75 (m, 4H), 6.27 (d, J = 3.6 Hz, 1H), 5.14 $(\mathrm{d}, \mathrm{J}=3.6 \mathrm{~Hz}, 1 \mathrm{H}), 5.08(\mathrm{~d}, \mathrm{~J}=3.6 \mathrm{~Hz}, 1 \mathrm{H}), 4.48(\mathrm{~m}, 2 \mathrm{H}), 4.35(\mathrm{dd}, \mathrm{J}=9.3,3.3 \mathrm{~Hz}, 1 \mathrm{H}), 3.94$ (m, 2H), $3.22(\mathrm{~m}, 3 \mathrm{H}), 1.45$ (s, 3H), 1.38 (s,3H), 1.28 (s, 6H). ${ }^{13} \mathbf{C}$ NMR (CDCl, 75 MHz, ठ): $163.5,143.6,134.6,128.8,124.3,123.5,112.4,109.6,106.2,83.5,80.5,72.2,67.3,65.6$, 26.8, 26.7, 26.1, 25.1, 24.9. HRMS (M+Na) ${ }^{+}$Calculatedfor $\mathrm{C}_{24} \mathrm{H}_{28} \mathrm{~N}_{4} \mathrm{O}_{8} \mathrm{Na}: 523.1805$, Found: 523.1811. 


\section{Synthesis of tetramer 18:}

Synthetic procedure is similar to compound 10; Yield (75\%)

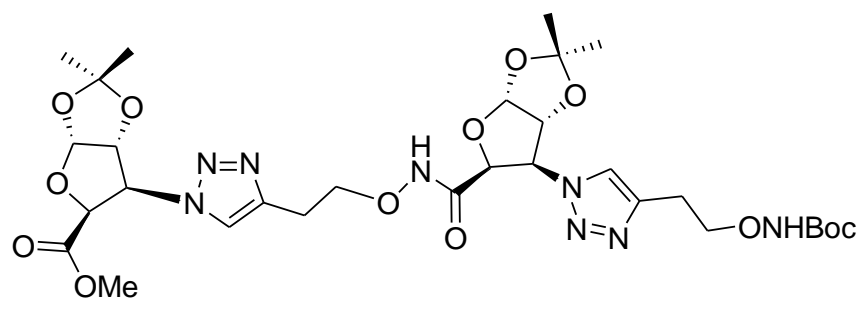

\section{Compound 18}

${ }^{1}$ HNMR (CDCl3, 600 MHz, $)$ ): 9.05 (s, 1H), 7.72 (s, 1H), 7.67 (s, 1H), 7.62 (s, 1H), 6.37 (d, J $=3.6 \mathrm{~Hz}, 1 \mathrm{H}), 6.33(\mathrm{~d}, \mathrm{~J}=3.6 \mathrm{~Hz}, 1 \mathrm{H}), 5.37(\mathrm{~d}, \mathrm{~J}=4.2 \mathrm{~Hz}, 1 \mathrm{H}), 5.29(\mathrm{~d}, \mathrm{~J}=4.2 \mathrm{~Hz}, 1 \mathrm{H})$, $5.13(\mathrm{~d}, \mathrm{~J}=4.2 \mathrm{~Hz}, 1 \mathrm{H}), 5.11(\mathrm{~m}, 2 \mathrm{H}), 5.02(\mathrm{~d}, \mathrm{~J}=3.6 \mathrm{~Hz}, 1 \mathrm{H}), 4.05(\mathrm{~m}, 2 \mathrm{H}), 3.78(\mathrm{~m}, 2 \mathrm{H})$, $3.00(\mathrm{~m}, 2 \mathrm{H}), 2.83(\mathrm{~m}, 2 \mathrm{H}), 1.62(\mathrm{~s}, 6 \mathrm{H}), 1.47(\mathrm{~s}, 9 \mathrm{H}), 1.38(\mathrm{~s}, 6 \mathrm{H}) .{ }^{13} \mathbf{C}$ NMR (CDCl3, 150 MHz, ס):167.0, 163.3, 157.0, 144.8, 144.4, 123.9, 122.4, 113.4, 113.1, 106.7, 106.0, 83.3, $83.0,81.8,80.0,78.3,75.2,74.6,66.2,65.6,52.6,28.2,26.8,26.7,26.3,26.2,24.6,24.5$. HRMS (M+Na) ${ }^{+}$Calculated for $\mathrm{C}_{30} \mathrm{H}_{44} \mathrm{~N}_{8} \mathrm{O}_{13} \mathrm{Na}: 747.2926$, Found: 747.2921. 


\section{Structural Determination by Multidimensional NMR:}

NMR Spectra (1D and 2D) of the pseudo cyclic peptide10and acyclic compound 18were recorded by Bruker Avance- $600 \mathrm{MHz}$ with TCI CYROPROBE in acetonitrile- $\mathrm{d}_{3}$ or $(2: 3)$ $\mathrm{CDCl}_{3}: \mathrm{CCl}_{4}$ or $\mathrm{CDCl}_{3}$ using tetramethylsilane as internal standard and chemical shifts are shown in ppm. All the two dimensional NMR studies (DQF COSY, ROESY) were carried out in phase-sensitive mode. The 2D spectra were acquired with $2 \times 256$ or $2 \times 192$ free induction decays (FID) containing 16-32 scans with relaxation delays of 1.5s. The ROESY experiments were performed with mixing time of 0.2 to $0.3 \mathrm{~s}$ and the TOCSY experiments were performed with mixing time of $0.02 \mathrm{~s}$. The two dimensional data were processed with Gaussian apodization in both the dimensions. The spectra (One Dimensional, DQF-COSY and ROESY) are given in the supporting information.

${ }^{1} \mathrm{H}-{ }^{1} \mathrm{H}$ ROESY cross peaks at $300 \mathrm{~ms}$ were assigned and integrated and the respective volumes were converted to distance restraints. When symmetric pairs of cross peaks were present, the larger peak volume was converted to the distance restraint. Cross-peaks were categorized as strong, medium, weak, and very weak based on their intensities. Inter-proton distances (r) were derived from the ROE intensities (S) with the known relationship $r=c(S)^{-}$ $1 / 6$, where $\mathrm{c}$ is a coefficient determined on the basis of ROE corresponding to a known distance. The distance constraints were determined from volume integrals of ROESY cross peaks using reference distance $2.40 \AA$ for vicinal cis-sugar ring protons. The conservative upper distances were fixed respectively as 3.5, 4.0, 4.5 and $6.0 \AA$ and the lower distance limit was fixed at $2.0 \AA$. Corrections of $0.1 \AA$ were applied to the upper bound distances derived from NOEs to account for any spin diffusion effect. The dihedral angles $(\varphi)$ were calculated from the ${ }^{3} \mathrm{~J}_{\mathrm{HN}-\mathrm{H} \beta}$ coupling constants measured from the ${ }^{1} \mathrm{H}-{ }^{1} \mathrm{H}$ DQF-COSY spectra using the modified Karplus equation. The $\varphi$ values thus obtained were used as dihedral restraints. 
Proton NMR Analysis

${ }^{1} \mathrm{H}$ NMR spectral data $\left(\mathrm{CDCl}_{3}\right)$ of Table-1 were assigned from the corresponding doublequantum-filtered 2D DQF-COSY as well as ROESY spectra.

\begin{tabular}{|c|c|c|c|c|c|c|}
\hline $\begin{array}{l}\text { Residue } \\
\text { name }\end{array}$ & $\mathbf{H}_{\alpha}$ & $\mathbf{H}_{\beta}$ & $\mathbf{H}_{\boldsymbol{\beta}^{\prime}}$ & $\mathbf{H}_{\gamma}$ & $\mathbf{H}_{\delta}$ & $\begin{array}{l}\text { Tr-H/- } \\
\text { ONH }\end{array}$ \\
\hline $\mathbf{S}$ & $\begin{array}{l}5.10(\mathrm{~d}) \\
\mathrm{J}=4.2 \mathrm{~Hz}\end{array}$ & $\begin{array}{l}5.24(\mathrm{~d}) \\
\mathrm{J}=4.2 \mathrm{~Hz}\end{array}$ & & $\begin{array}{l}5.28(\mathrm{~d}) \\
\mathrm{J}=3.6 \mathrm{~Hz}\end{array}$ & $\begin{array}{l}6.46(d) \\
J=3.6 \mathrm{~Hz}\end{array}$ & $7.79(\mathrm{~s})$ \\
\hline Pro & & $\begin{array}{l}4.50(\mathrm{~d}) \\
\mathrm{J}=11.2 \mathrm{~Hz}\end{array}$ & $\begin{array}{l}4.75(\mathrm{~d}) \\
\mathrm{J}=11.2 \mathrm{~Hz}\end{array}$ & & & $9.52(\mathrm{~s})$ \\
\hline
\end{tabular}

Other signals: $1.25,1.39(2 \times \mathrm{Me})$

Table S1: ${ }^{1} \mathrm{H}$ NMR data $\left(\mathrm{CDCl}_{3}, 600 \mathrm{MHz}, 300 \mathrm{~K}\right)$ of compound 10showing chemical shifts (ppm) and coupling constants (Hz)

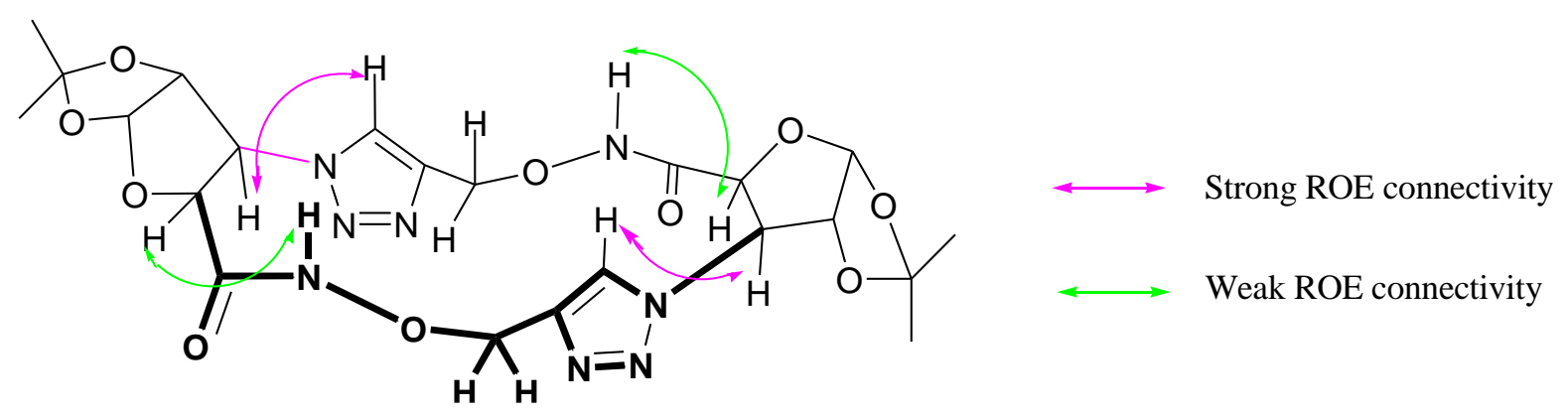

Figure S3: Strong and weak ROE connectivities in peptidomimetic macrocycle 10 observed by 2D NMR spectroscopy 


\section{Molecular Modeling Studies:}

Construction of molecular model and structural analysis of different obtained conformations were achieved by Discovery studio 4.0. The Discover software was used for molecular modeling calculation and also energy minimization. The energy minimized structure was obtained by using a modifiedCHARMmforce field. Structure refinement was carried out by incorporating NMR derived distance and torsion angle constraints. Energy minimization of each structure was carried out by steepest descent method followed by conjugate gradient method, until an RMS deviation of 0.001 Kcal was arrived.
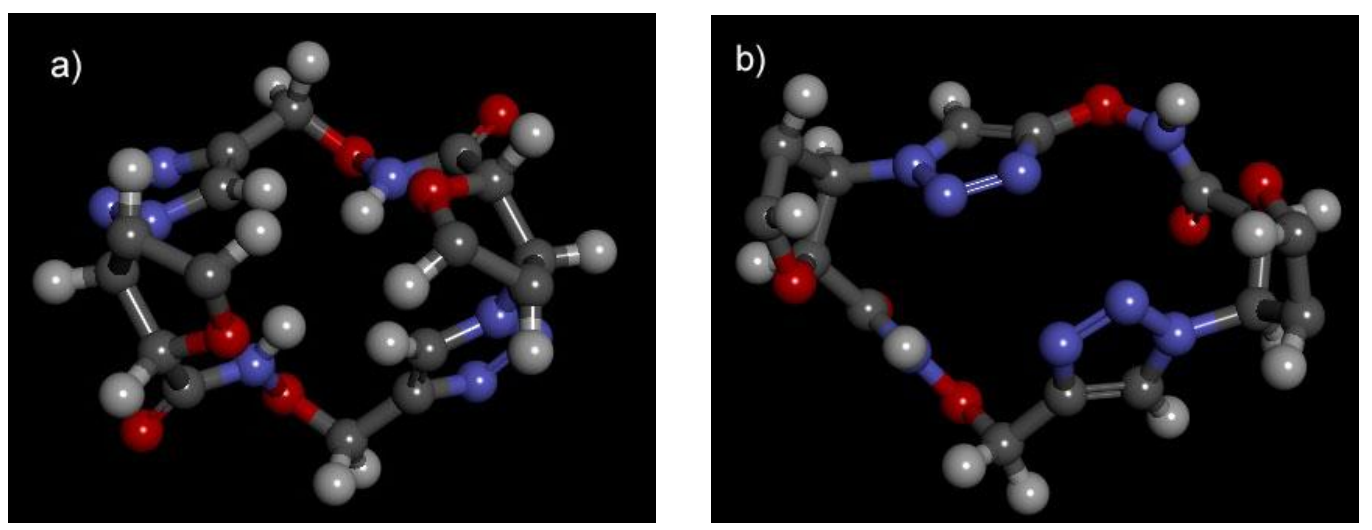

Figure S4: Two possible lowest energy conformations of triazole/aminoxy based peptidomimetic macrocycle 10: (a) a structure resembling the D-,L- $\alpha$-aminoxy acid based cyclic peptides, (b) a structure resembling aminoxy/amide based hybrid cyclic peptides. Isopropylidene moieties are omitted for the sake of clarity. 
8. ${ }^{1} \mathrm{H},{ }^{13} \mathrm{C}$ NMR, 2D NMR, Mass and FT-IR Spectra:

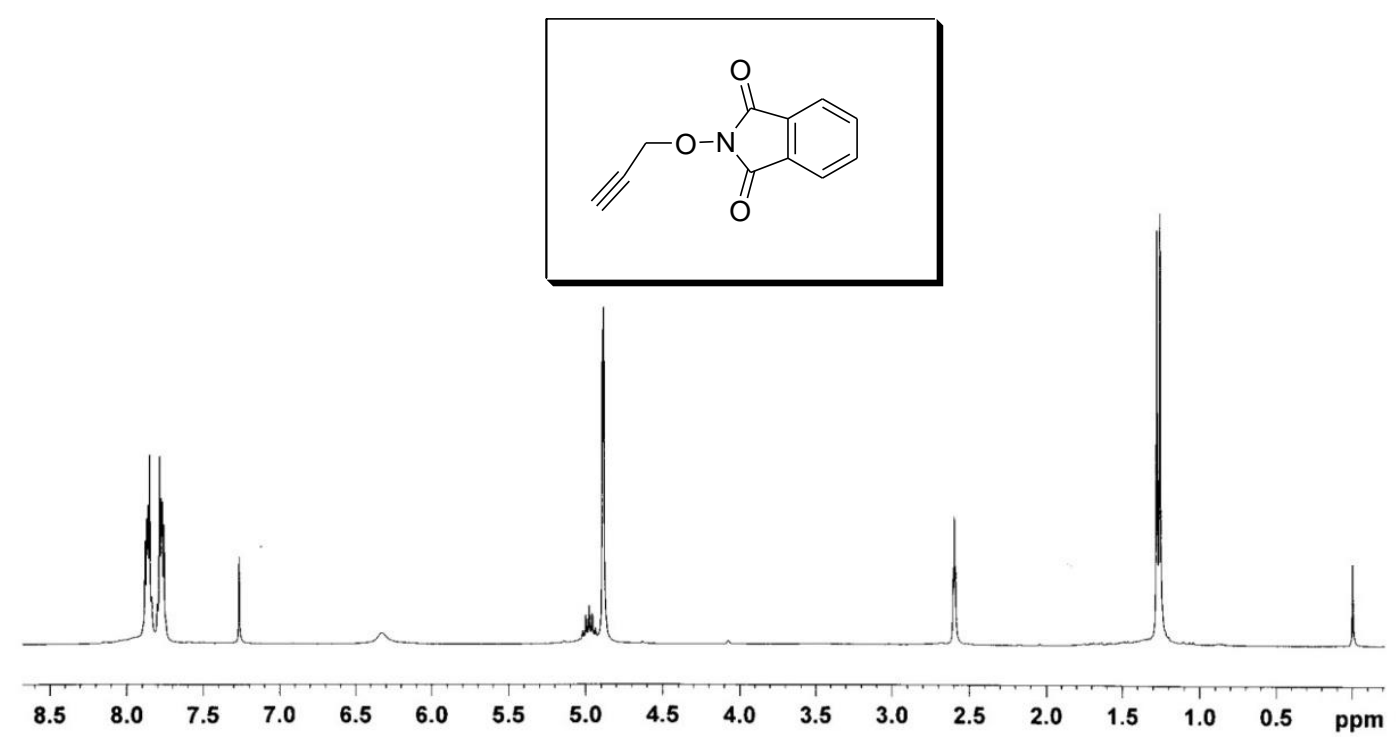

Figure S5: ${ }^{1} \mathrm{H}$ NMR of compound $1 \mathrm{in} \mathrm{CDCl}_{3}$ at $298 \mathrm{~K}$

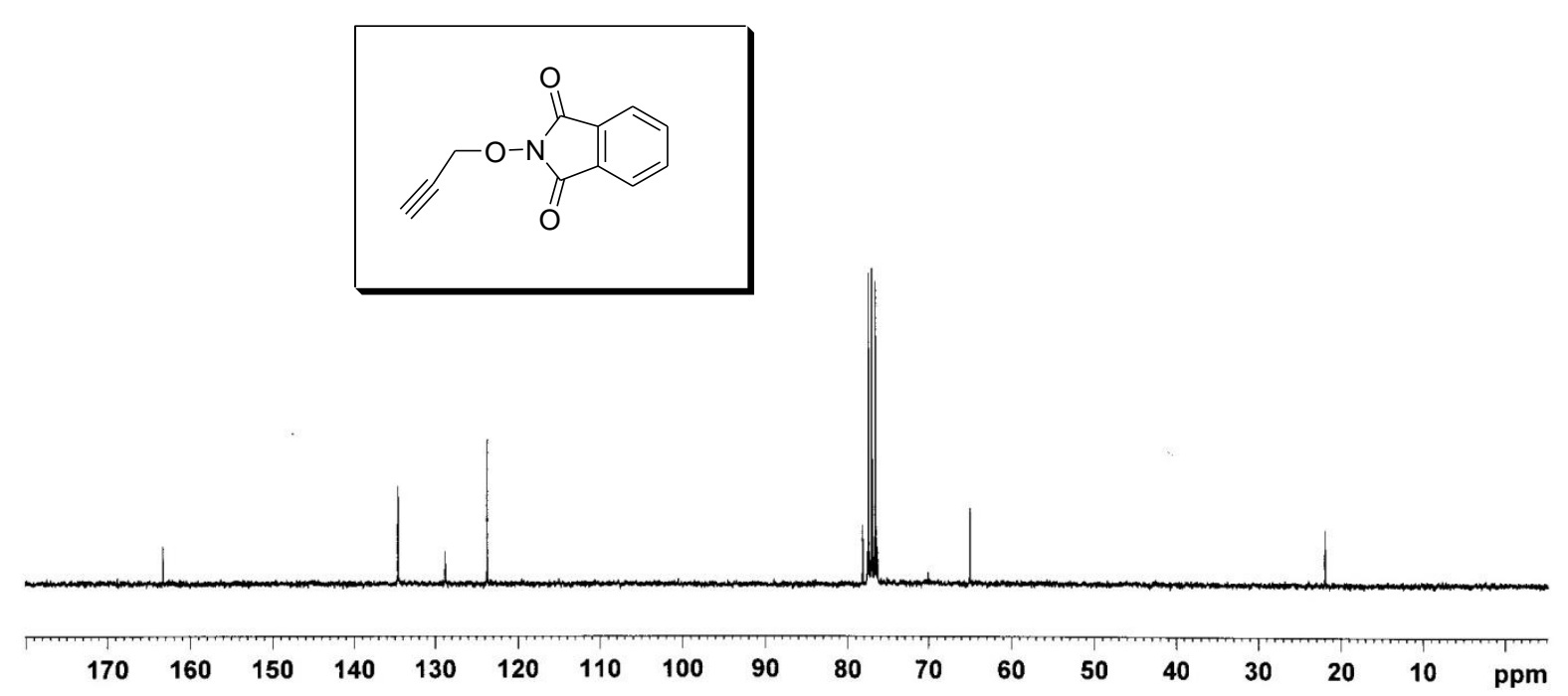

Figure S6: ${ }^{13} \mathrm{C}$ NMR of compound 1 in $\mathrm{CDCl}_{3}$ at $298 \mathrm{~K}$ 


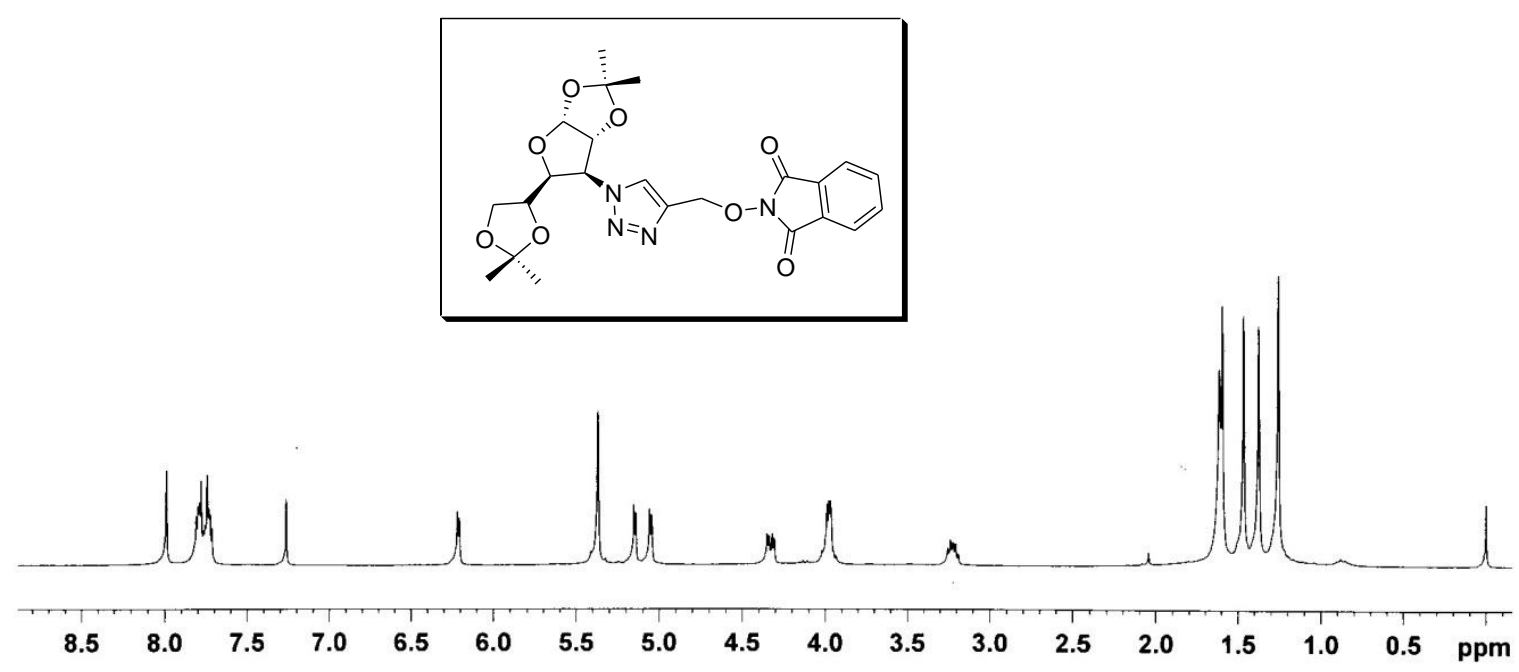

Figure S7: ${ }^{1} \mathrm{H}$ NMR of compound 3 in $\mathrm{CDCl}_{3}$ at $298 \mathrm{~K}$

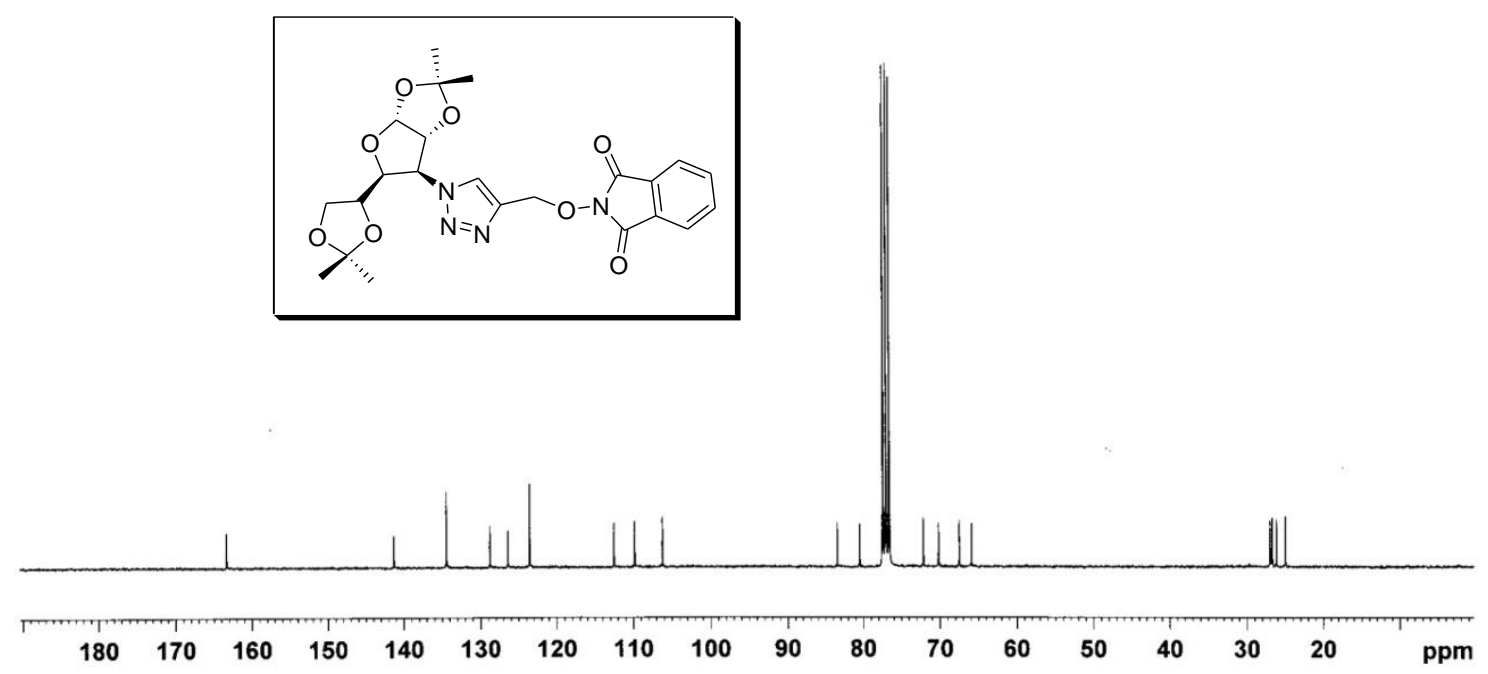

Figure S8: ${ }^{13} \mathrm{C}$ NMR of compound 3 in $\mathrm{CDCl}_{3}$ at $298 \mathrm{~K}$ 


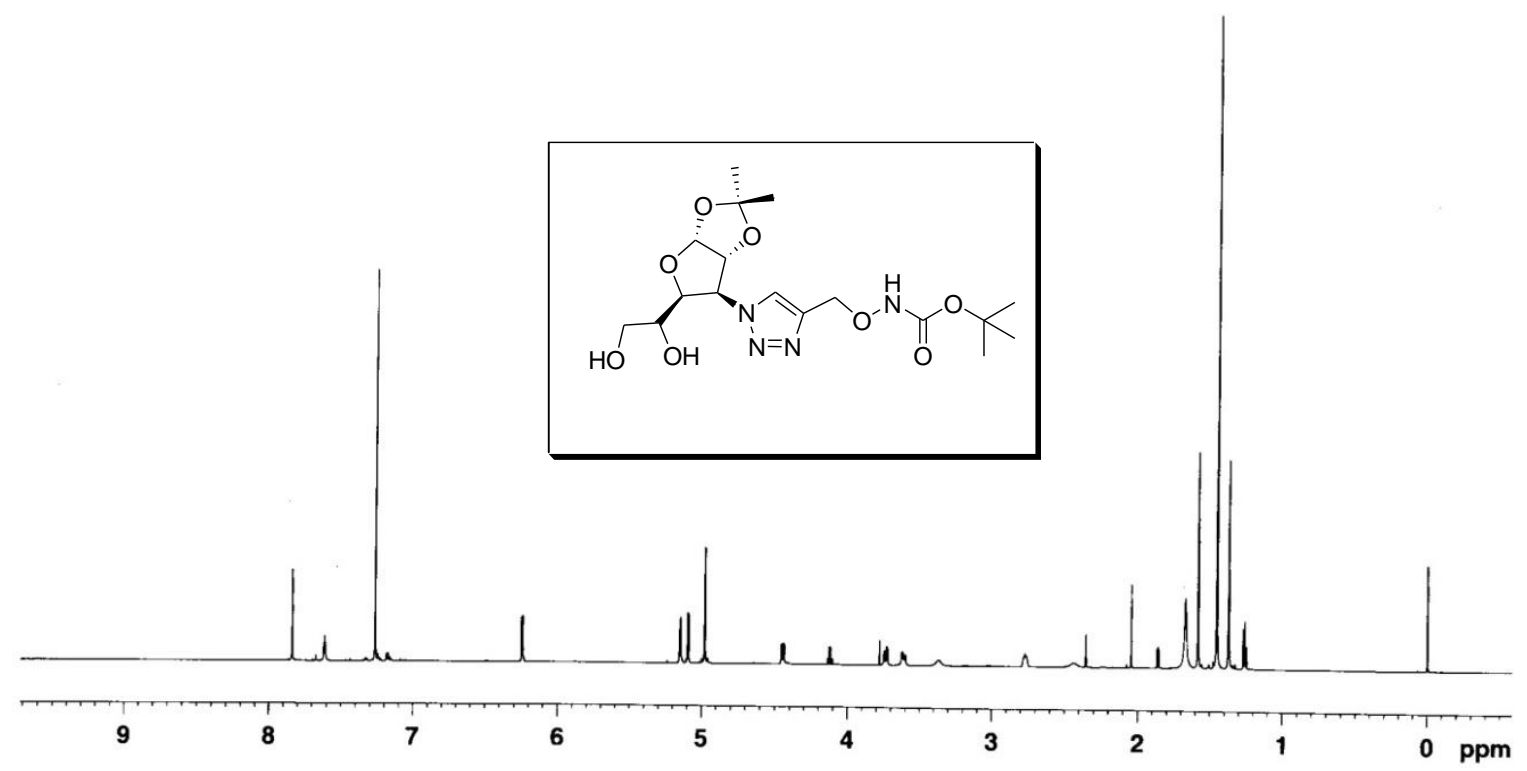

Figure S9: ${ }^{1} \mathrm{H}$ NMR of compound 5 in $\mathrm{CDCl}_{3}$ at $298 \mathrm{~K}$

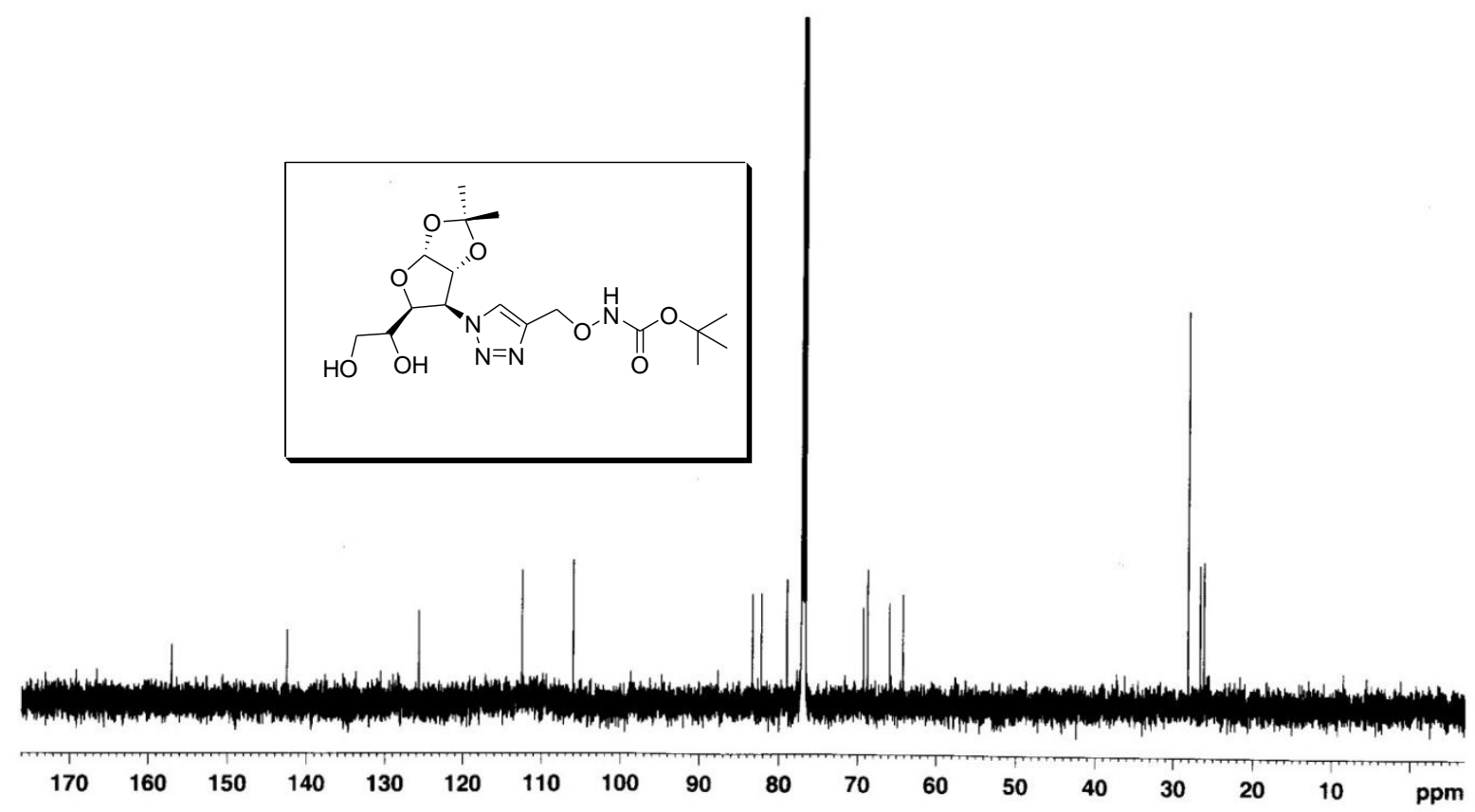

Figure S10: ${ }^{13} \mathrm{C}$ NMR of compound 5 in $\mathrm{CDCl}_{3}$ at $298 \mathrm{~K}$ 


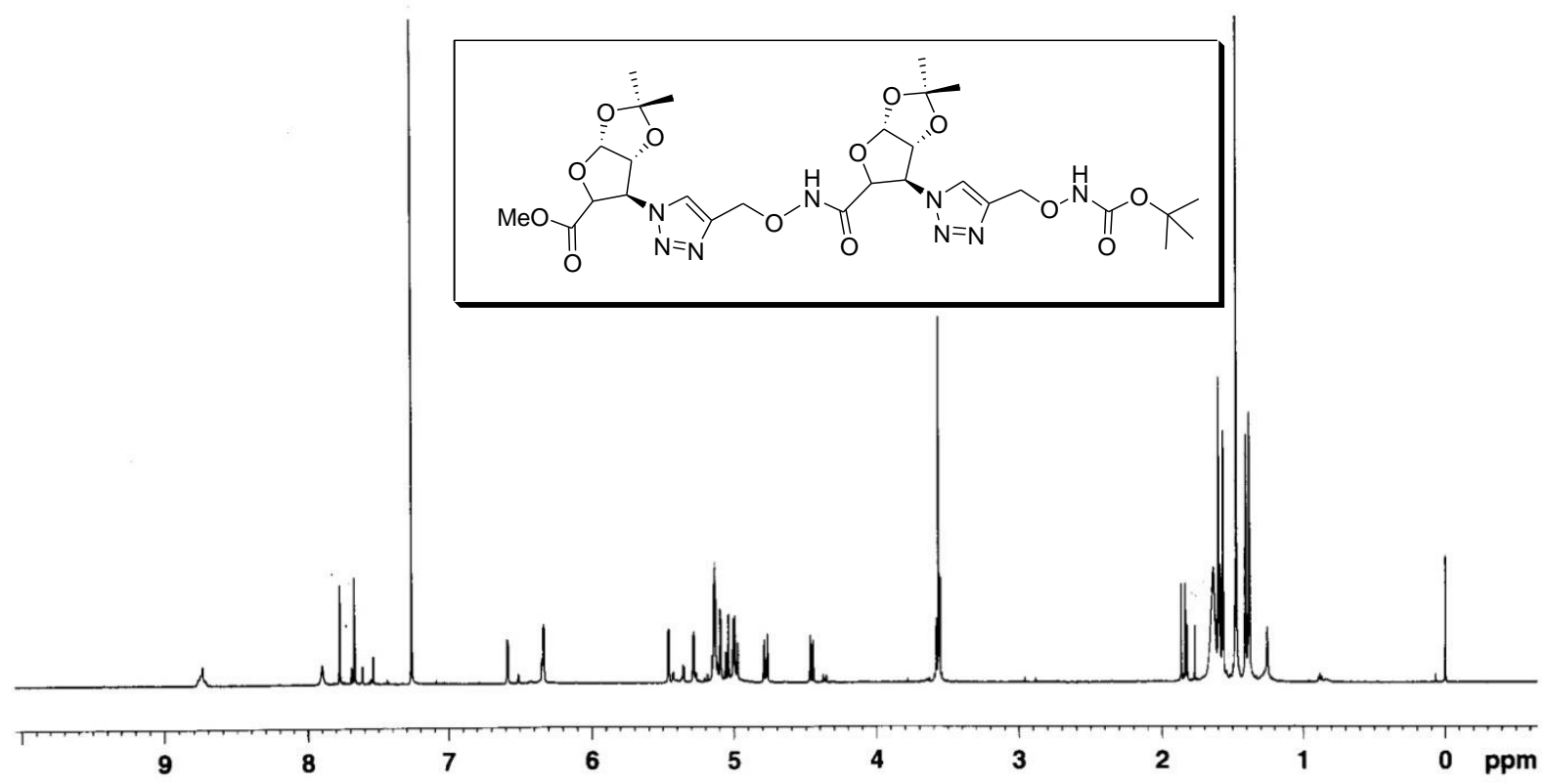

Figure S11: ${ }^{1} \mathrm{H}$ NMR of compound 9 in $\mathrm{CDCl}_{3}$ at $298 \mathrm{~K}$

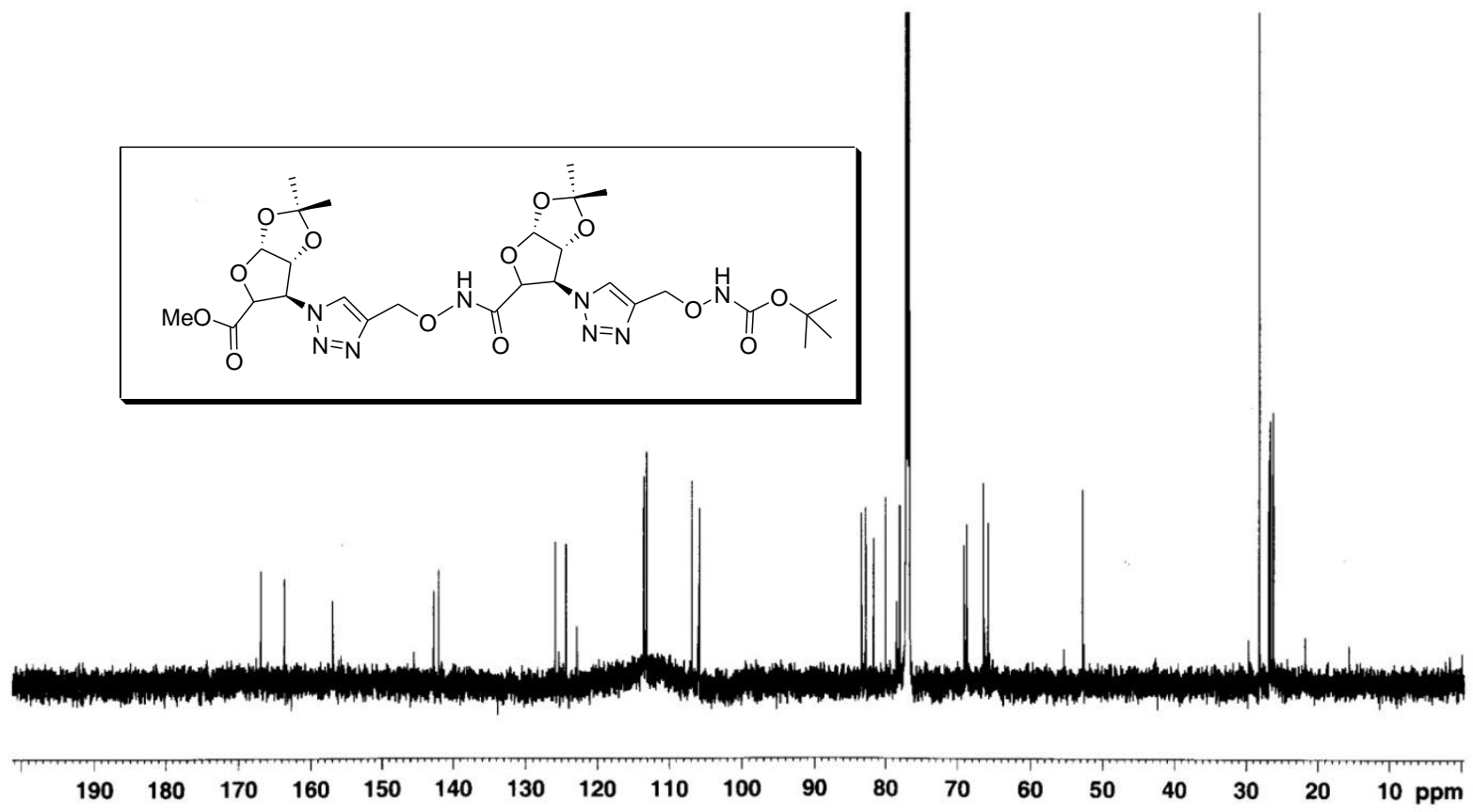

Figure S12: ${ }^{13} \mathrm{C}$ NMR of compound 9 in $\mathrm{CDCl}_{3}$ at $298 \mathrm{~K}$ 


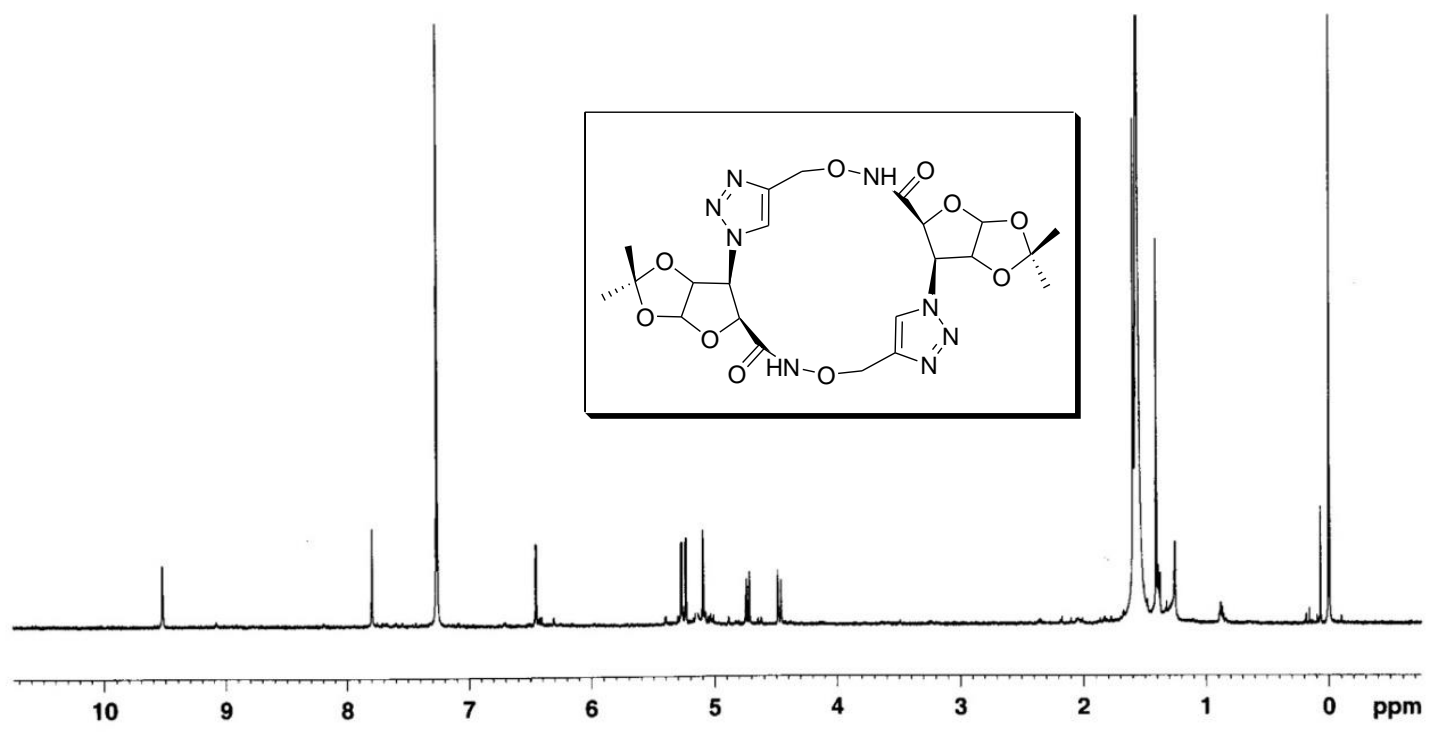

Figure S13: ${ }^{1} \mathrm{H}$ NMR (600 MHz) of compound 10 in $\mathrm{CDCl}_{3}$ at $298 \mathrm{~K}$

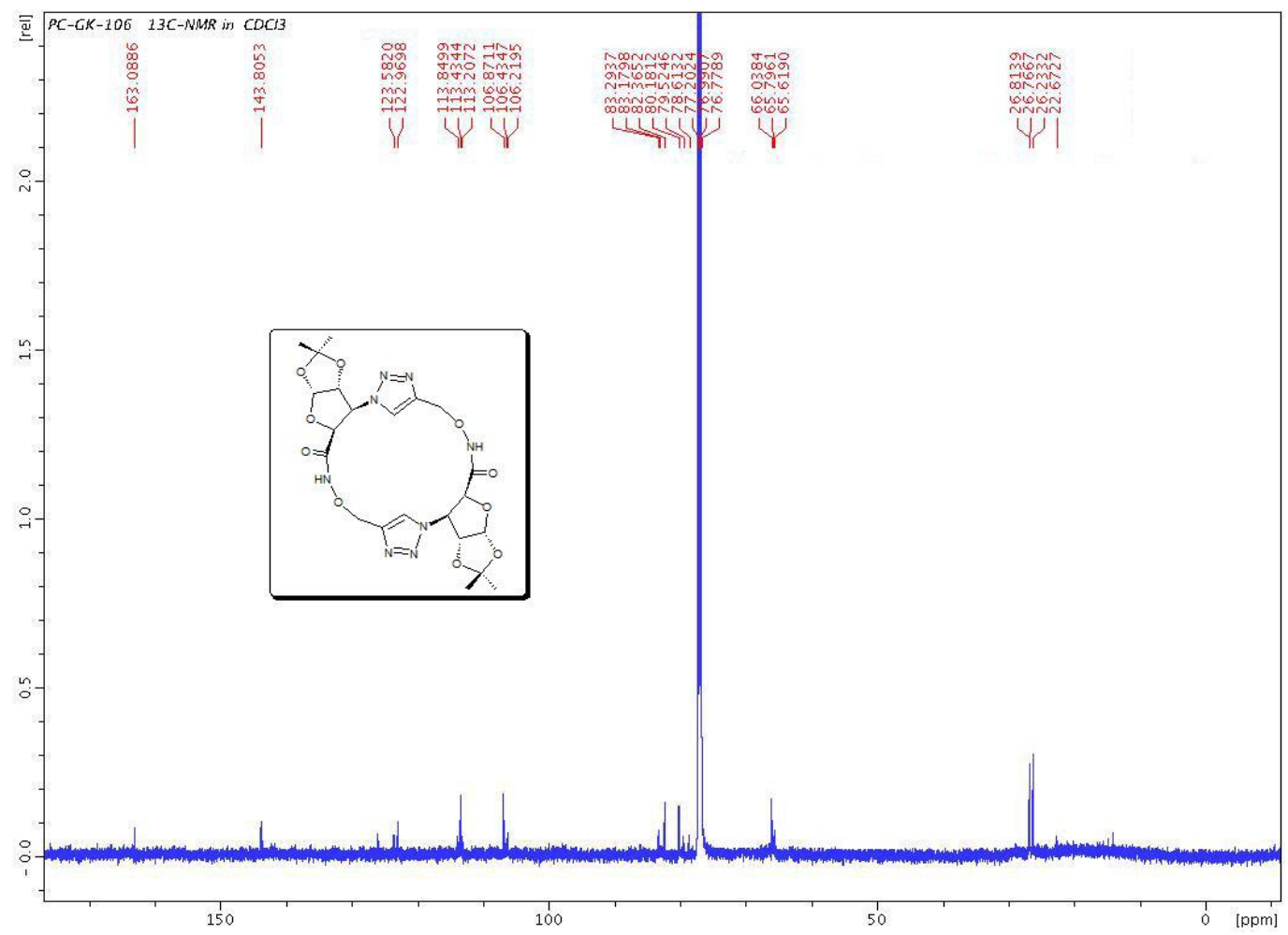

Figure S14: ${ }^{13} \mathrm{C}$ NMR (150 MHz) of compound 10 in $\mathrm{CDCl}_{3}$ at $298 \mathrm{~K}$ 


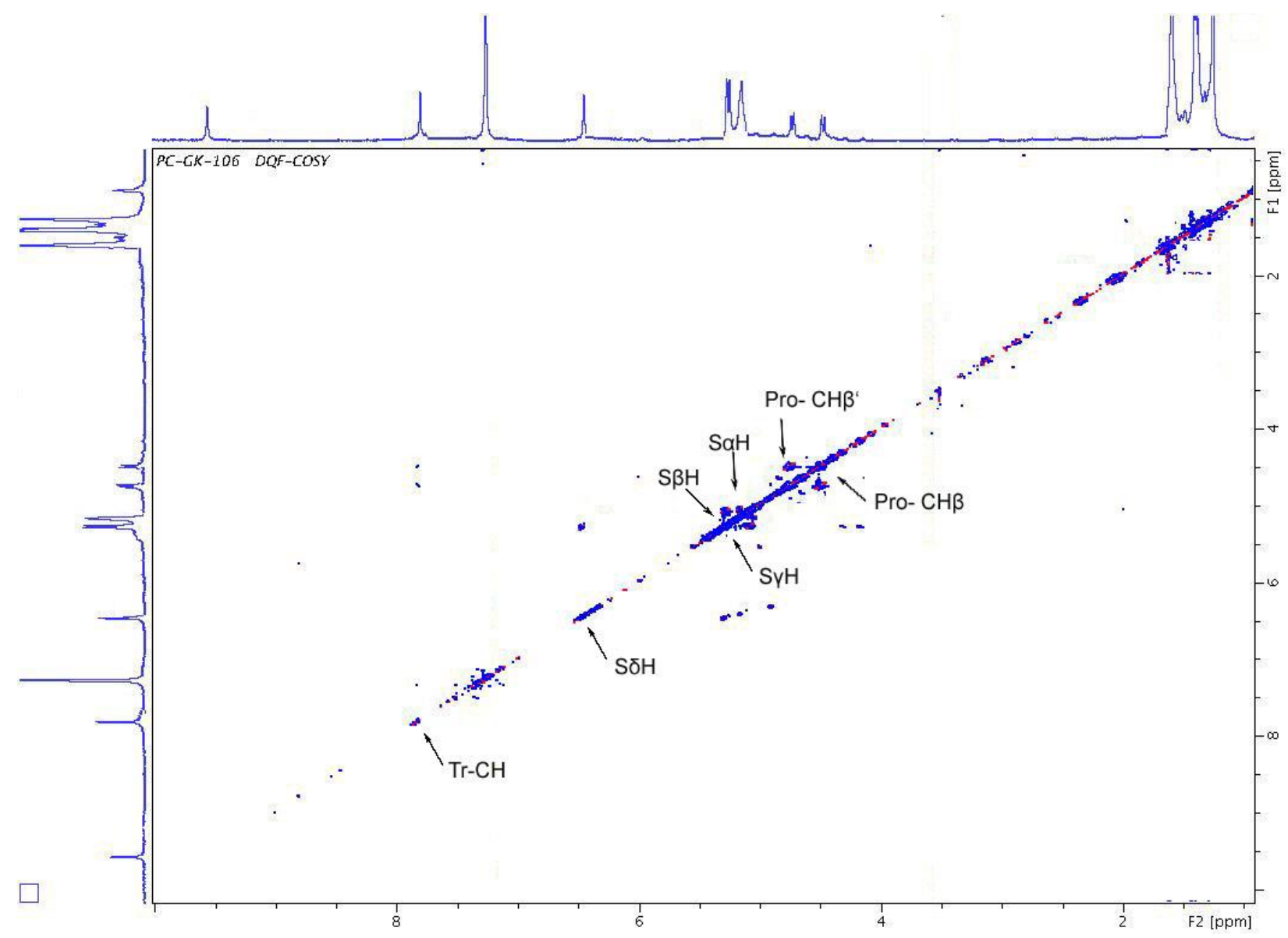

Figure S15: ${ }^{1} \mathrm{H}-{ }^{1} \mathrm{H}$ DQF-COSY $(600 \mathrm{MHz})$ of the cyclic peptide 10 recorded in $\mathrm{CDCl}_{3}$ (10 $\mathrm{mM}$ ) at 298K 


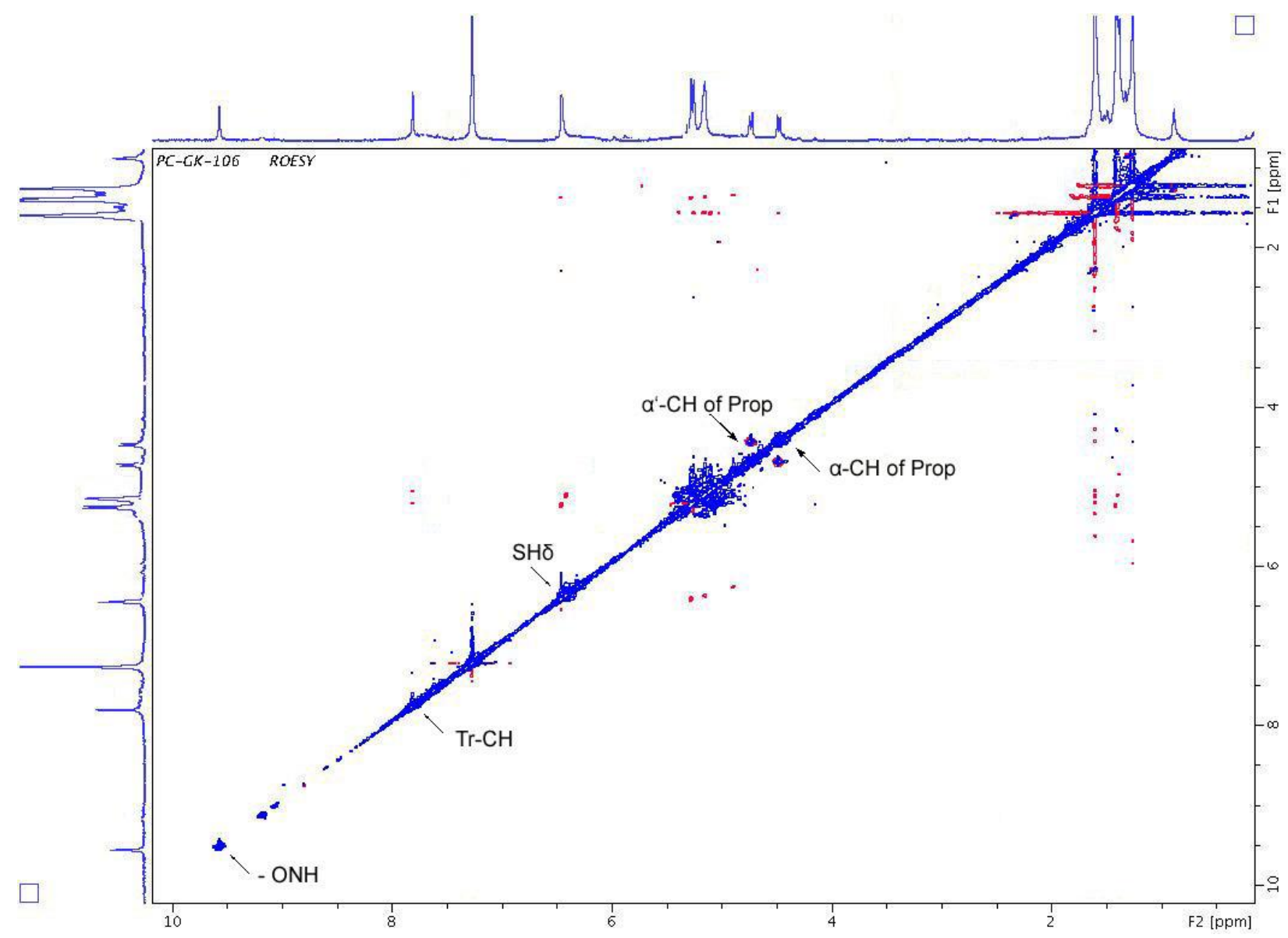

Figure S16: ${ }^{1} \mathrm{H}-{ }^{1} \mathrm{H}$ ROESY (600 $\left.\mathrm{MHz}\right)$ of cyclic peptide 10 recorded in $\mathrm{CDCl}_{3}(10 \mathrm{mM})$ at $298 \mathrm{~K}$ 


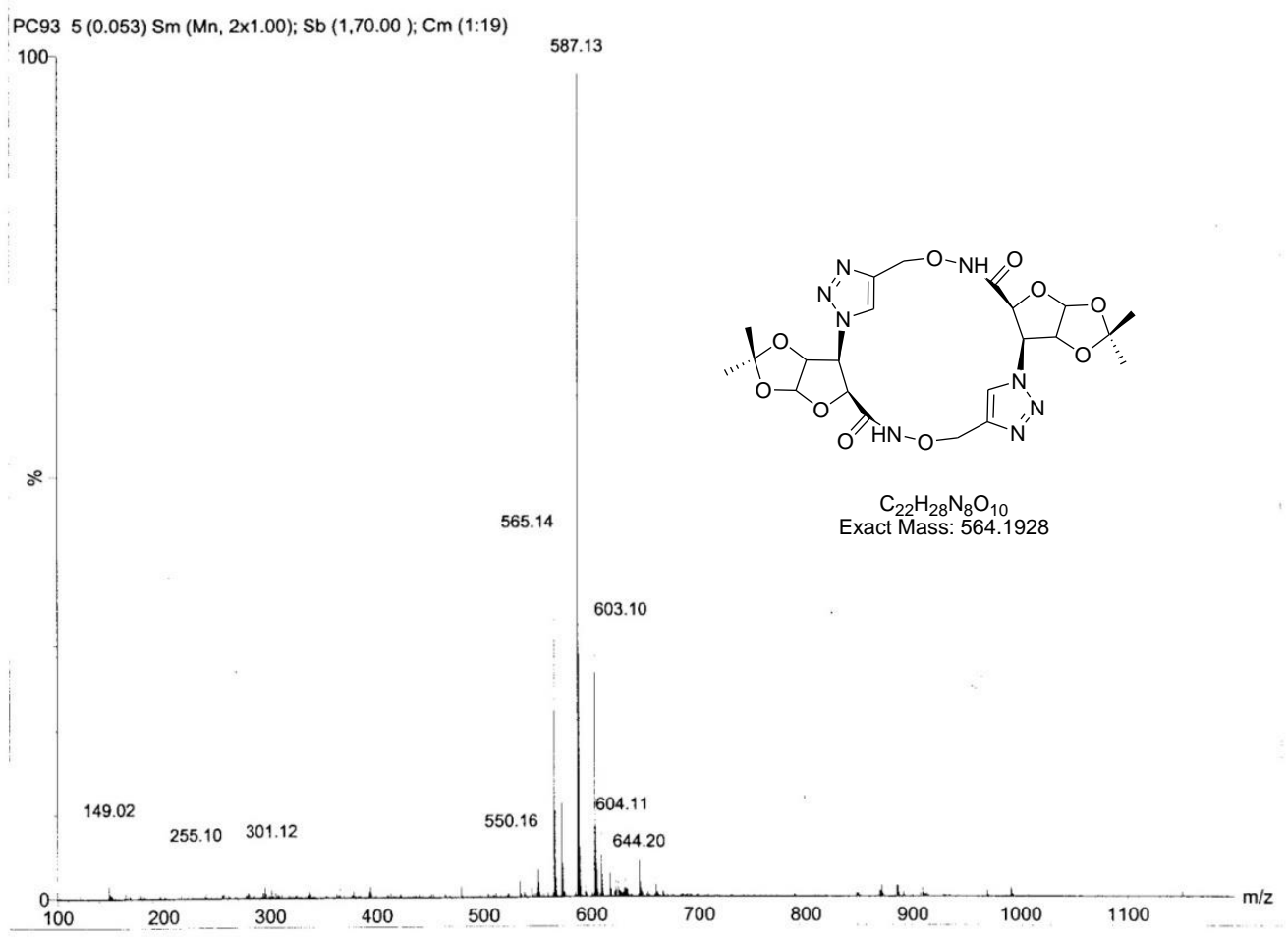

Figure S17: ESI mass spectrum of compound 10 dissolved in DCM. 


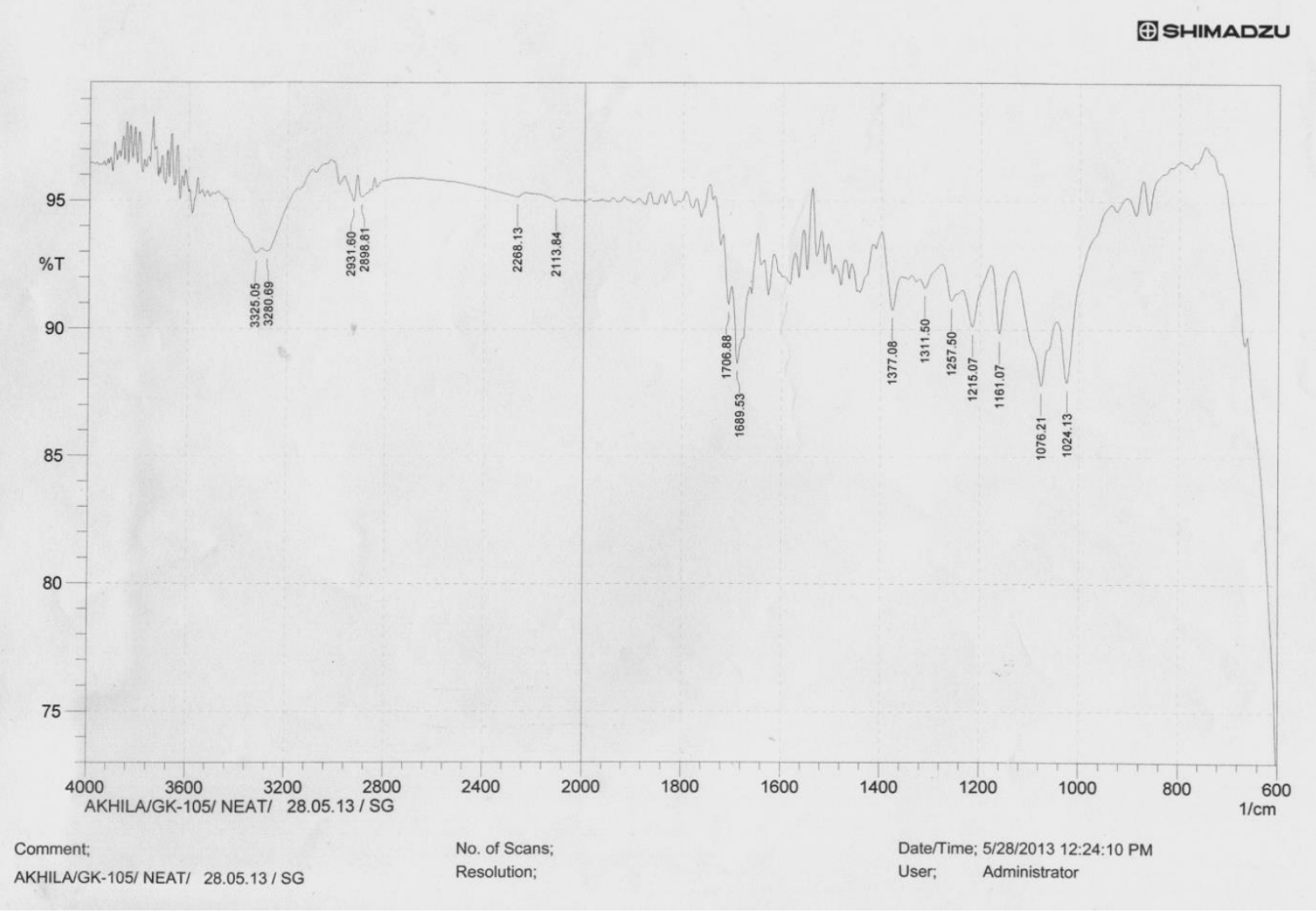

Figure S18: FT-IR spectrum recorded on a JASCO FT/IR-400 spectrophotometer using 5-10 mM solution in $\mathrm{CHCl}_{3}$ of compound 10 takenin a $\mathrm{NaCl}$ cell 


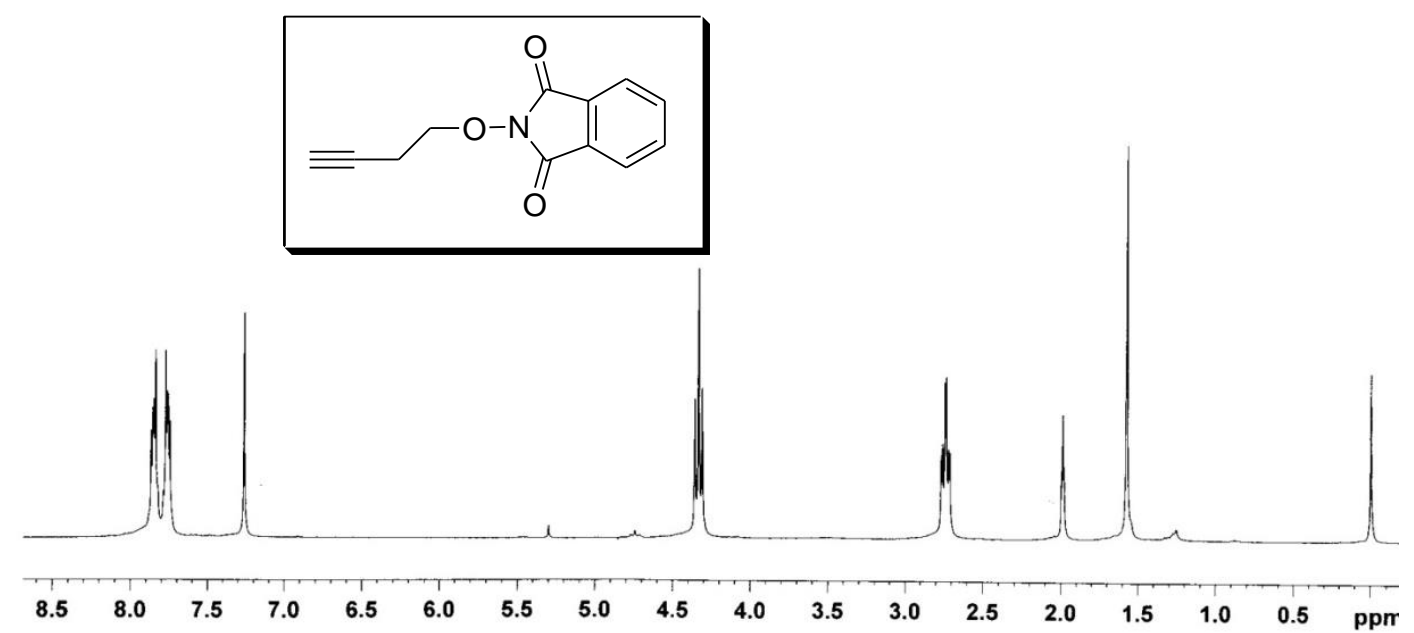

Figure S19: ${ }^{1} \mathrm{H}$ NMR of compound 11 in $\mathrm{CDCl}_{3}$ at $298 \mathrm{~K}$

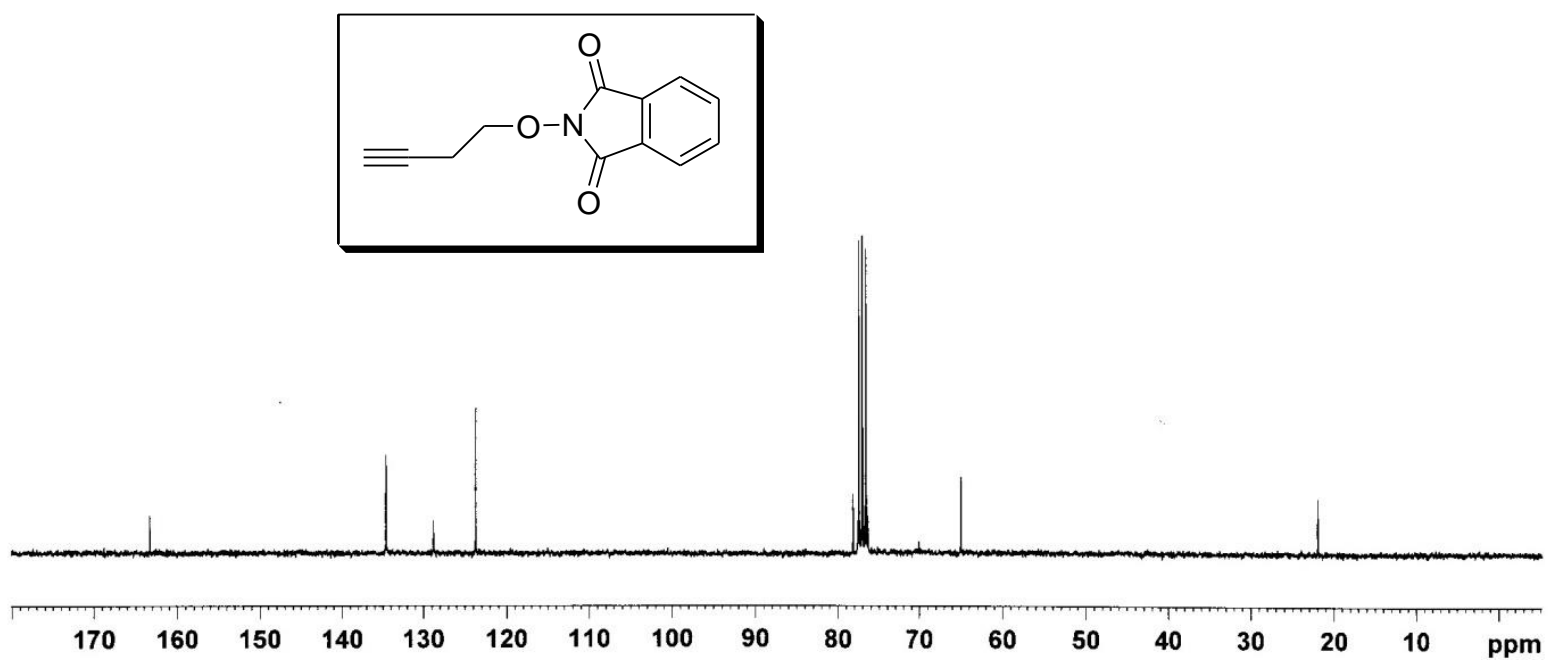

Figure S20: ${ }^{13} \mathrm{C}$ NMR of compound 11 in $\mathrm{CDCl}_{3}$ at $298 \mathrm{~K}$ 


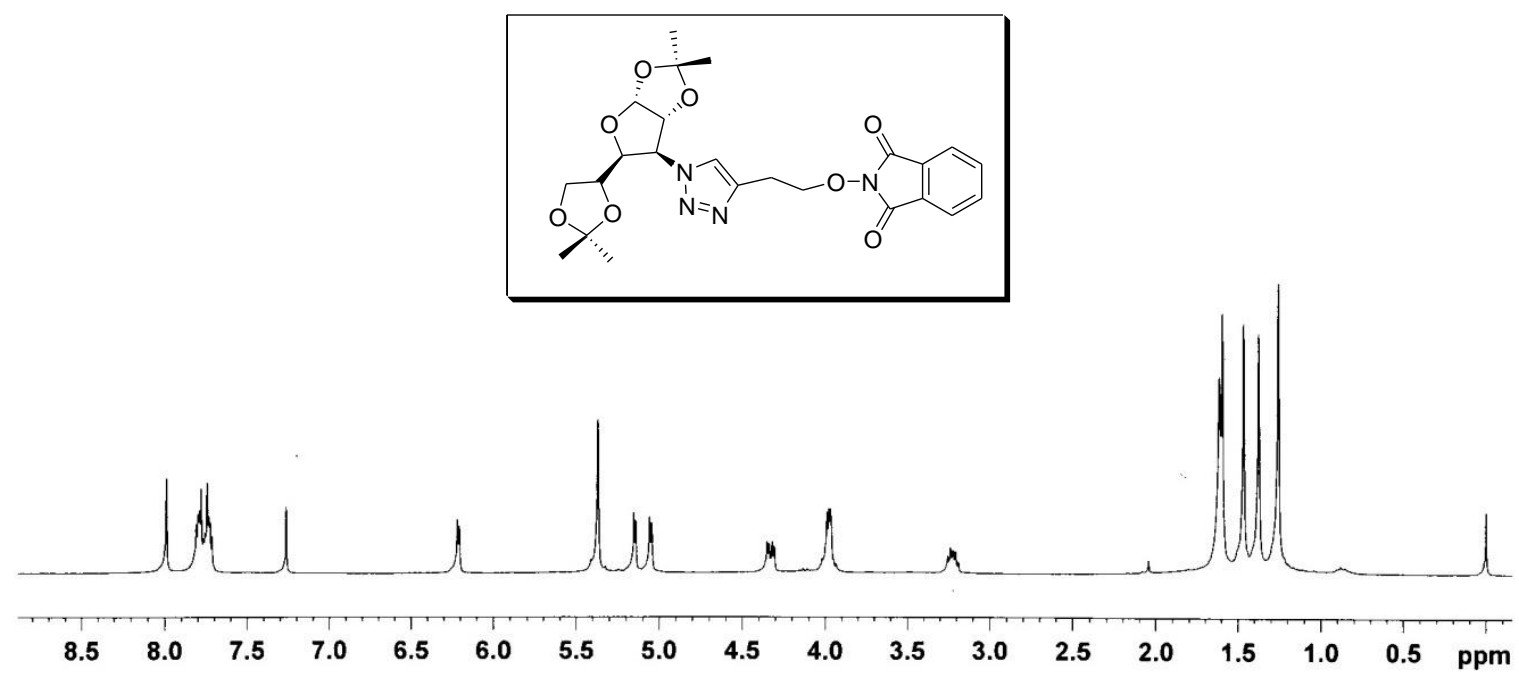

Figure S21: ${ }^{1} \mathrm{H}$ NMR of compound 12 in $\mathrm{CDCl}_{3}$ at $298 \mathrm{~K}$
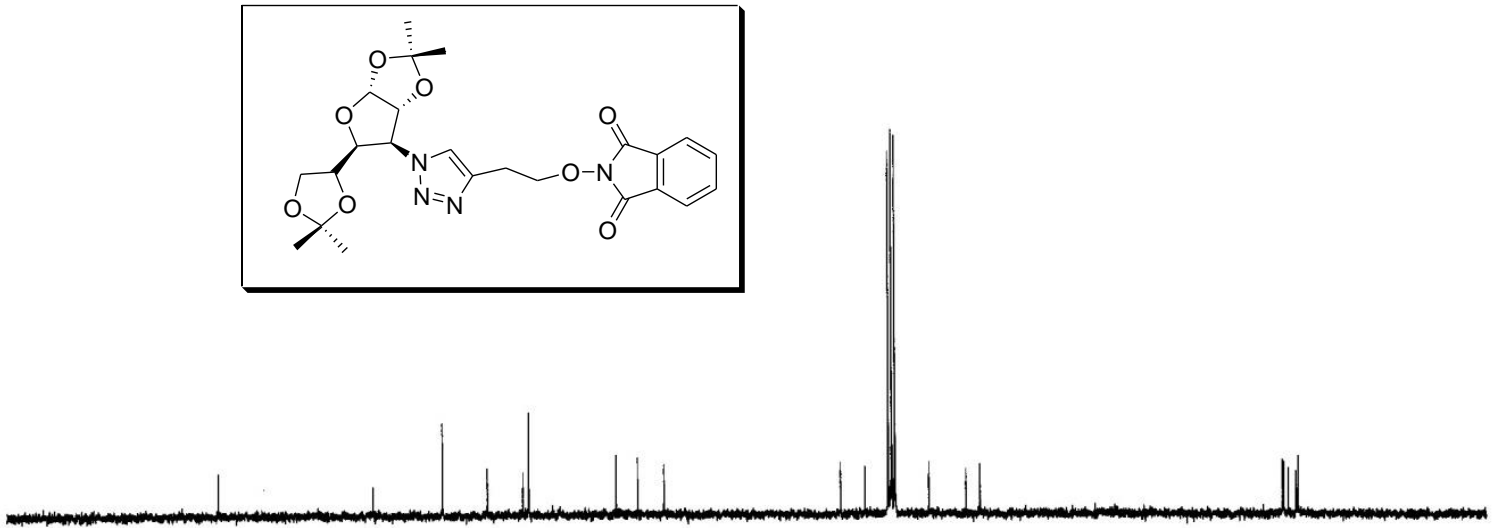

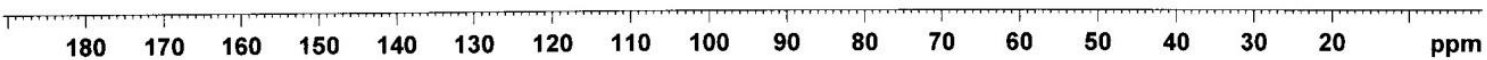

Figure S22: ${ }^{13} \mathrm{C}$ NMR of compound 12 in $\mathrm{CDCl}_{3}$ at $298 \mathrm{~K}$ 


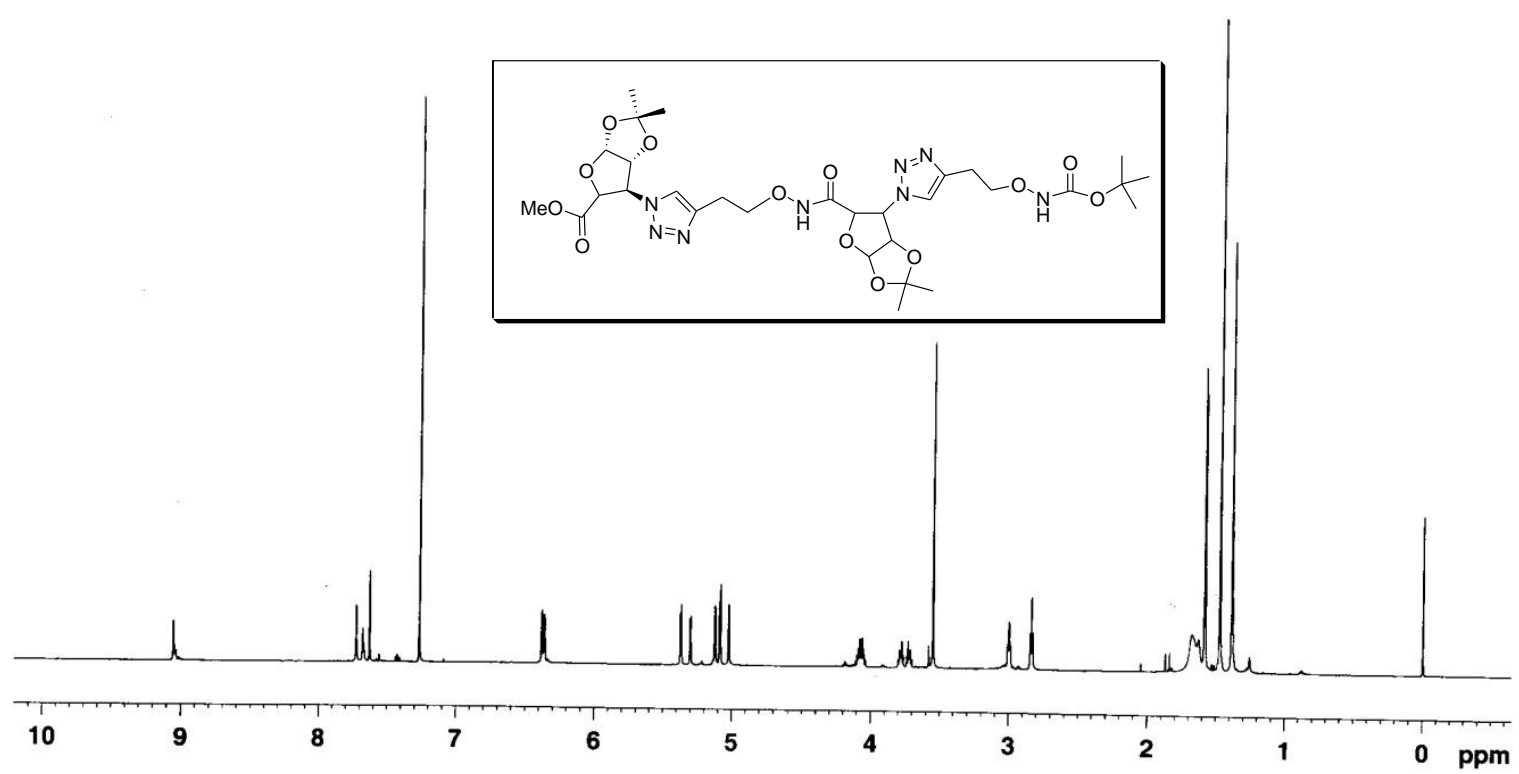

Figure S23: ${ }^{1} \mathrm{H}$ NMR of compound 18 in $\mathrm{CDCl}_{3}$ at $298 \mathrm{~K}$

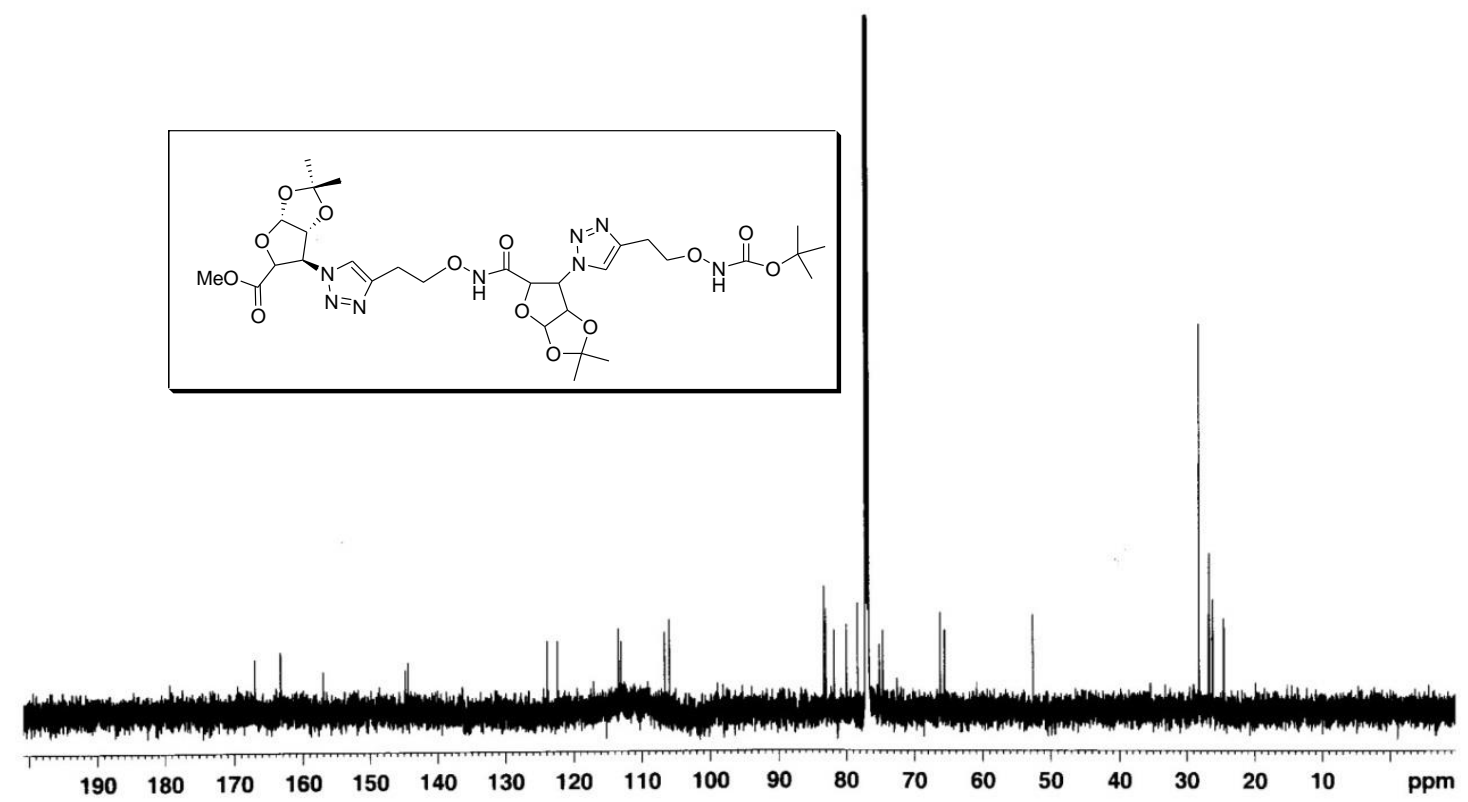

Figure S24: ${ }^{13} \mathrm{C}$ NMR of compound 18 in $\mathrm{CDCl}_{3}$ at $298 \mathrm{~K}$ 


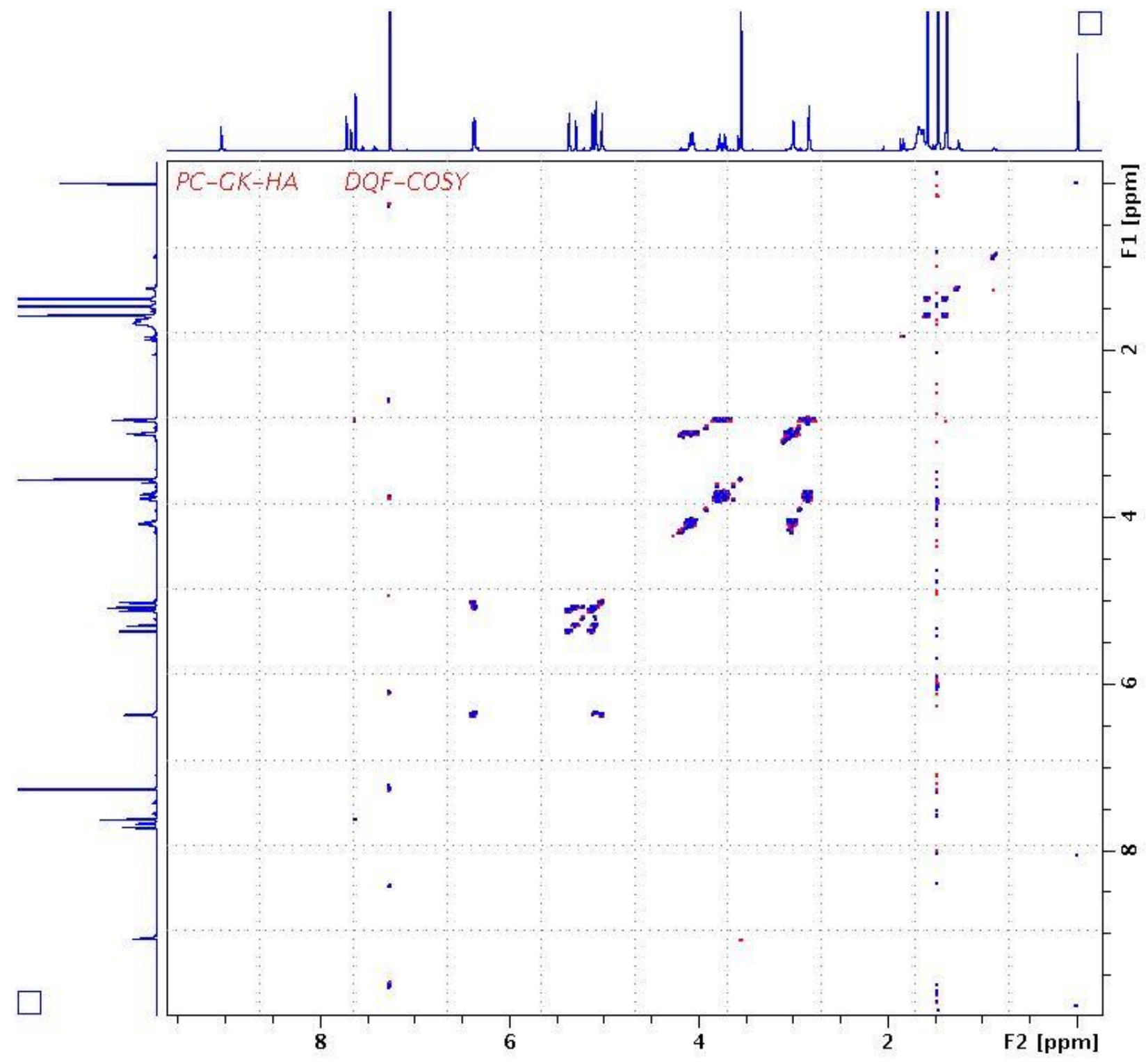

Figure S25: ${ }^{1} \mathrm{H}-{ }^{1} \mathrm{H}$ DQF-COSY (600 MHz) of acyclic peptide 18 recorded in $\mathrm{CDCl}_{3}(10$ $\mathrm{mM}$ ) at $298 \mathrm{~K}$ 


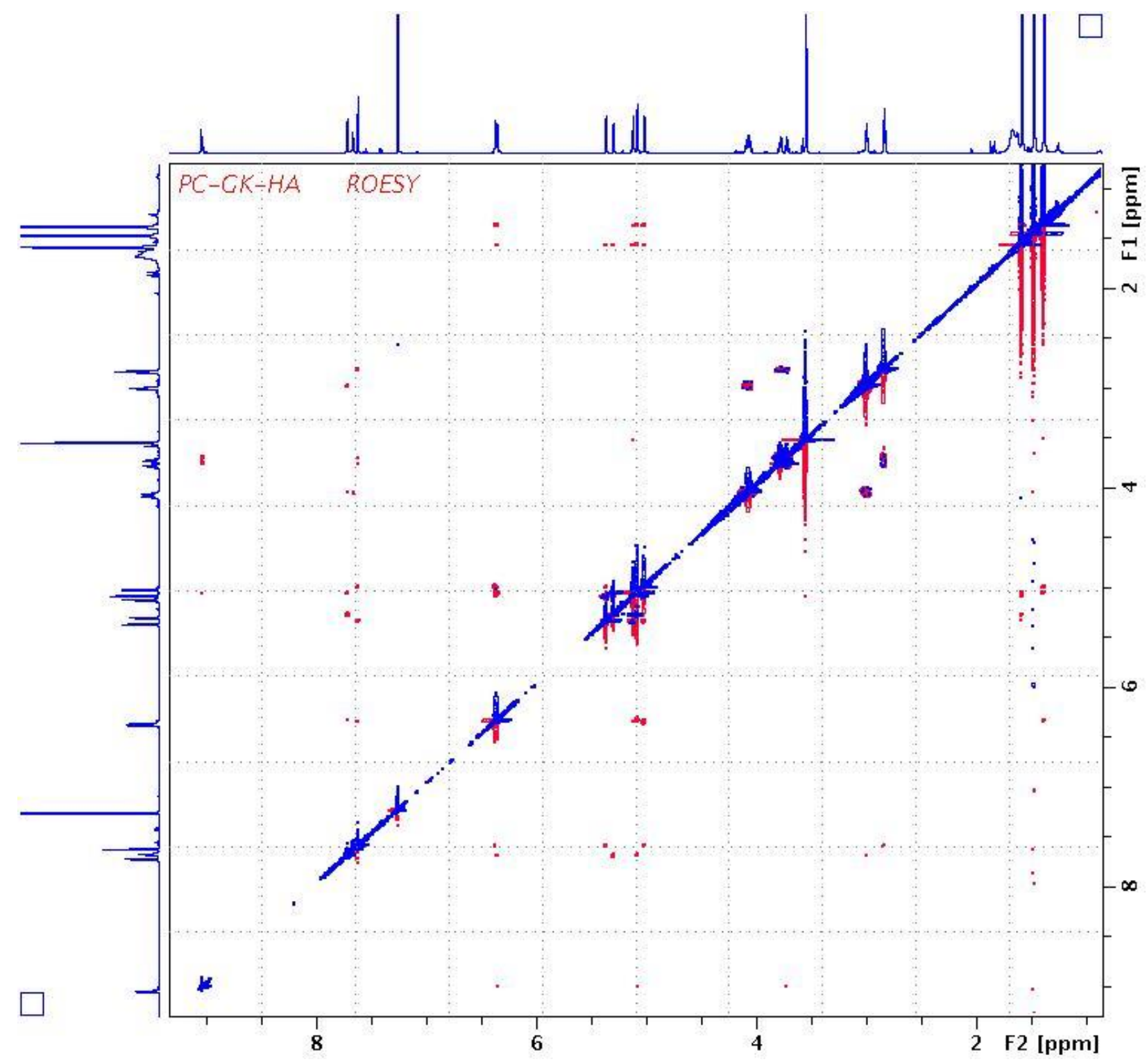

Figure S26: ${ }^{1} \mathrm{H}-{ }^{1} \mathrm{H}$ ROESY (600 MHz) of acyclic peptide 18 recorded in $\mathrm{CDCl}_{3}(10 \mathrm{mM})$ at $298 \mathrm{~K}$ 


\section{Molecular Modeling Co-ordinates:}

\section{Co-ordinates of the compound 10:}

\begin{tabular}{|c|c|c|c|c|c|c|c|c|c|}
\hline REMARK & ACC & elrys & S Dis & ery & dio PDB & file & & & \\
\hline REMARK & Cre & ated: & $: \quad 20$ & $11-$ & $15: 44: 57 z$ & & & & \\
\hline $\begin{array}{l}\text { HETATM } \\
\mathrm{C}\end{array}$ & 1 & $\mathrm{C} 12$ & UNK & 0 & -9.267 & 4.203 & 1.744 & 1.00 & 0.00 \\
\hline $\begin{array}{l}\text { HETATM } \\
\mathrm{C}\end{array}$ & 2 & $\mathrm{C} 14$ & UNK & 0 & -10.078 & 3.525 & 2.854 & 1.00 & 0.00 \\
\hline $\begin{array}{l}\text { HETATM } \\
\mathrm{C}\end{array}$ & 3 & C32 & UNK & 0 & -10.821 & -0.893 & 3.469 & 1.00 & 0.00 \\
\hline $\begin{array}{l}\text { HETATM } \\
\mathrm{C}\end{array}$ & 4 & C45 & UNK & 0 & -6.074 & -1.104 & 5.253 & 1.00 & 0.00 \\
\hline $\begin{array}{l}\text { HETATM } \\
\text { C }\end{array}$ & 5 & C56 & UNK & 0 & -5.225 & -0.351 & 4.221 & 1.00 & 0.00 \\
\hline $\begin{array}{l}\text { HETATM } \\
\mathrm{N}\end{array}$ & 6 & N4 8 & UNK & 0 & -6.334 & -0.260 & 2.082 & 1.00 & 0.00 \\
\hline $\begin{array}{l}\text { HETATM } \\
\mathrm{H}\end{array}$ & 7 & $4 \mathrm{H} 58$ & UNK & 0 & -6.912 & 0.414 & 2.541 & 1.00 & 0.00 \\
\hline $\begin{array}{l}\text { HETATM } \\
\mathrm{C}\end{array}$ & 8 & C55 & UNK & 0 & -6.236 & 0.568 & -0.089 & 1.00 & 0.00 \\
\hline $\begin{array}{l}\text { HETATM } \\
\text { O }\end{array}$ & 9 & 058 & UNK & 0 & -6.536 & -0.543 & 0.728 & 1.00 & 0.00 \\
\hline $\begin{array}{l}\text { HETATM } \\
\mathrm{C}\end{array}$ & 10 & C53 & UNK & 0 & -5.354 & -0.863 & 2.777 & 1.00 & 0.00 \\
\hline $\begin{array}{l}\text { HETATM } \\
\text { O }\end{array}$ & 11 & 057 & UNK & 0 & -4.609 & -1.726 & 2.331 & 1.00 & 0.00 \\
\hline $\begin{array}{l}\text { HETATM } \\
\mathrm{H}\end{array}$ & 12 & H3 & UNK & 0 & -11.338 & -0.320 & 4.240 & 1.00 & 0.00 \\
\hline $\begin{array}{l}\text { HETATM } \\
\mathrm{H}\end{array}$ & 13 & $\mathrm{H} 6$ & UNK & 0 & -11.426 & -1.773 & 3.252 & 1.00 & 0.00 \\
\hline $\begin{array}{l}\text { HETATM } \\
\mathrm{H}\end{array}$ & 14 & H17 & UNK & 0 & -9.912 & 4.848 & 1.146 & 1.00 & 0.00 \\
\hline $\begin{array}{l}\text { HETATM } \\
0\end{array}$ & 15 & 031 & UNK & 0 & -10.689 & -0.118 & 2.296 & 1.00 & 0.00 \\
\hline $\begin{array}{l}\text { HETATM } \\
\mathrm{N}\end{array}$ & 16 & N37 & UNK & 0 & -7.423 & -1.464 & 4.761 & 1.00 & 0.00 \\
\hline $\begin{array}{l}\text { HETATM } \\
\mathrm{H}\end{array}$ & 17 & $\mathrm{H} 48$ & UNK & 0 & -5.560 & -2.011 & 5.574 & 1.00 & 0.00 \\
\hline $\begin{array}{l}\text { HETATM } \\
\mathrm{C}\end{array}$ & 18 & C39 & UNK & 0 & -8.404 & -0.562 & 4.483 & 1.00 & 0.00 \\
\hline $\begin{array}{l}\text { HETATM } \\
\mathrm{N}\end{array}$ & 19 & N4 2 & UNK & 0 & -7.746 & -2.774 & 4.541 & 1.00 & 0.00 \\
\hline $\begin{array}{l}\text { HETATM } \\
\mathrm{C}\end{array}$ & 20 & $\mathrm{C} 1$ & UNK & 0 & -9.462 & -1.330 & 3.975 & 1.00 & 0.00 \\
\hline $\begin{array}{l}\text { HETATM } \\
\mathrm{H}\end{array}$ & 21 & $\mathrm{H} 62$ & UNK & 0 & -8.380 & 0.509 & 4.613 & 1.00 & 0.00 \\
\hline $\begin{array}{l}\text { HETATM } \\
\mathrm{N}\end{array}$ & 22 & N2 & UNK & 0 & -8.992 & -2.587 & 4.037 & 1.00 & 0.00 \\
\hline $\begin{array}{l}\text { HETATM } \\
\mathrm{N}\end{array}$ & 23 & N4 0 & UNK & 0 & -10.123 & 1.132 & 2.563 & 1.00 & 0.00 \\
\hline $\begin{array}{l}\text { HETATM } \\
\mathrm{H}\end{array}$ & 24 & H87 & UNK & 0 & -9.177 & 1.192 & 2.880 & 1.00 & 0.00 \\
\hline $\begin{array}{l}\text { HETATM } \\
\text { C }\end{array}$ & 25 & $\mathrm{C} 40$ & UNK & 0 & -10.839 & 2.260 & 2.422 & 1.00 & 0.00 \\
\hline
\end{tabular}




\begin{tabular}{|c|c|c|c|c|c|c|c|c|c|}
\hline $\begin{array}{l}\text { HETATM } \\
\text { O }\end{array}$ & 26 & 043 & UNK & 0 & -11.991 & 2.312 & 2.011 & 1.00 & 0.00 \\
\hline $\begin{array}{l}\text { HETATM } \\
\mathrm{C}\end{array}$ & 27 & C36 & UNK & 0 & -7.264 & 1.663 & 0.100 & 1.00 & 0.00 \\
\hline $\begin{array}{l}\text { HETATM } \\
\mathrm{H}\end{array}$ & 28 & $4 \mathrm{H} 10$ & UNK & 0 & -5.241 & 0.948 & 0.147 & 1.00 & 0.00 \\
\hline $\begin{array}{l}\text { HETATM } \\
\mathrm{H}\end{array}$ & 29 & $5 \mathrm{H} 10$ & UNK & 0 & -6.228 & 0.254 & -1.133 & 1.00 & 0.00 \\
\hline $\begin{array}{l}\text { HETATM } \\
\mathrm{C}\end{array}$ & 30 & $\mathrm{C} 2$ & UNK & 0 & -7.546 & 2.445 & 1.230 & 1.00 & 0.00 \\
\hline $\begin{array}{l}\text { HETATM } \\
\mathrm{N}\end{array}$ & 31 & N1 & UNK & 0 & -8.139 & 2.112 & -0.815 & 1.00 & 0.00 \\
\hline $\begin{array}{l}\text { HETATM } \\
\mathrm{N}\end{array}$ & 32 & N45 & UNK & 0 & -8.577 & 3.248 & 0.847 & 1.00 & 0.00 \\
\hline $\begin{array}{l}\text { HETATM } \\
\mathrm{H}\end{array}$ & 33 & $8 \mathrm{H} 11$ & UNK & 0 & -7.054 & 2.405 & 2.189 & 1.00 & 0.00 \\
\hline $\begin{array}{l}\text { HETATM } \\
\mathrm{N}\end{array}$ & 34 & N3 & UNK & 0 & -8.975 & 3.119 & -0.454 & 1.00 & 0.00 \\
\hline $\begin{array}{l}\text { HETATM } \\
\text { O }\end{array}$ & 35 & 041 & UNK & 0 & -9.131 & 3.242 & 3.863 & 1.00 & 0.00 \\
\hline $\begin{array}{l}\text { HETATM } \\
\mathrm{H}\end{array}$ & 36 & OH13 & UNK & 0 & -10.806 & 4.231 & 3.257 & 1.00 & 0.00 \\
\hline $\begin{array}{l}\text { HETATM } \\
\mathrm{C}\end{array}$ & 37 & $C 47$ & UNK & 0 & -8.143 & 4.256 & 3.887 & 1.00 & 0.00 \\
\hline $\begin{array}{l}\text { HETATM } \\
\mathrm{C}\end{array}$ & 38 & C50 & UNK & 0 & -8.274 & 5.013 & 2.567 & 1.00 & 0.00 \\
\hline $\begin{array}{l}\text { HETATM } \\
\text { O }\end{array}$ & 39 & $\mathrm{O} 1$ & UNK & 0 & -8.854 & 6.243 & 2.919 & 1.00 & 0.00 \\
\hline $\begin{array}{l}\text { HETATM } \\
\mathrm{H}\end{array}$ & 40 & $7 \mathrm{H} 14$ & UNK & 0 & -7.318 & 5.186 & 2.072 & 1.00 & 0.00 \\
\hline $\begin{array}{l}\text { HETATM } \\
\mathrm{O}\end{array}$ & 41 & 046 & UNK & 0 & -5.640 & 0.994 & 4.335 & 1.00 & 0.00 \\
\hline $\begin{array}{l}\text { HETATM } \\
\mathrm{H}\end{array}$ & 42 & $9 \mathrm{H} 14$ & UNK & 0 & -4.173 & -0.410 & 4.504 & 1.00 & 0.00 \\
\hline $\begin{array}{l}\text { HETATM } \\
\mathrm{C}\end{array}$ & 43 & C52 & UNK & 0 & -5.978 & 1.277 & 5.681 & 1.00 & 0.00 \\
\hline $\begin{array}{l}\text { HETATM } \\
\mathrm{C}\end{array}$ & 44 & $\mathrm{C} 3$ & UNK & 0 & -6.145 & -0.074 & 6.373 & 1.00 & 0.00 \\
\hline $\begin{array}{l}\text { HETATM } \\
\text { O }\end{array}$ & 45 & 051 & UNK & 0 & -4.908 & 1.909 & 6.335 & 1.00 & 0.00 \\
\hline $\begin{array}{l}\text { HETATM } \\
\mathrm{H}\end{array}$ & 46 & $8 \mathrm{H} 16$ & UNK & 0 & -6.873 & 1.897 & 5.726 & 1.00 & 0.00 \\
\hline $\begin{array}{l}\text { HETATM } \\
\text { O }\end{array}$ & 47 & 054 & UNK & 0 & -5.009 & -0.197 & 7.191 & 1.00 & 0.00 \\
\hline $\begin{array}{l}\text { HETATM } \\
\mathrm{H}\end{array}$ & 48 & $2 \mathrm{H} 17$ & UNK & 0 & -7.046 & -0.138 & 6.984 & 1.00 & 0.00 \\
\hline $\begin{array}{l}\text { HETATM } \\
\mathrm{C}\end{array}$ & 49 & C5 7 & UNK & 0 & -4.377 & 1.057 & 7.325 & 1.00 & 0.00 \\
\hline $\begin{array}{l}\text { HETATM } \\
\mathrm{C}\end{array}$ & 50 & C54 & UNK & 0 & -4.701 & 1.635 & 8.705 & 1.00 & 0.00 \\
\hline $\begin{array}{l}\text { HETATM } \\
\mathrm{H}\end{array}$ & 51 & $2 \mathrm{H} 18$ & UNK & 0 & -4.331 & 0.986 & 9.498 & 1.00 & 0.00 \\
\hline $\begin{array}{l}\text { HETATM } \\
\mathrm{H}\end{array}$ & 52 & $3 \mathrm{H} 18$ & UNK & 0 & -5.778 & 1.742 & 8.835 & 1.00 & 0.00 \\
\hline $\begin{array}{l}\text { HETATM } \\
\mathrm{H}\end{array}$ & 53 & $4 \mathrm{H} 18$ & UNK & 0 & -4.248 & 2.619 & 8.833 & 1.00 & 0.00 \\
\hline $\begin{array}{l}\text { HETATM } \\
\text { C }\end{array}$ & 54 & $\mathrm{C} 4$ & UNK & 0 & -2.872 & 0.894 & 7.105 & 1.00 & 0.00 \\
\hline
\end{tabular}




\begin{tabular}{|c|c|c|c|c|c|c|c|c|c|}
\hline $\begin{array}{l}\text { HETATM } \\
\mathrm{H}\end{array}$ & 55 & $5 \mathrm{H} 18$ & UNK & 0 & -2.440 & 0.218 & 7.843 & 1.00 & 0.00 \\
\hline $\begin{array}{l}\text { HETATM } \\
\mathrm{H}\end{array}$ & 56 & $6 \mathrm{H} 18$ & UNK & 0 & -2.359 & 1.853 & 7.184 & 1.00 & 0.00 \\
\hline $\begin{array}{l}\text { HETATM } \\
\mathrm{H}\end{array}$ & 57 & $7 \mathrm{H} 18$ & UNK & 0 & -2.667 & 0.486 & 6.116 & 1.00 & 0.00 \\
\hline $\begin{array}{l}\text { HETATM } \\
\mathrm{O}\end{array}$ & 58 & 060 & UNK & 0 & -8.426 & 5.195 & 4.893 & 1.00 & 0.00 \\
\hline $\begin{array}{l}\text { HETATM } \\
\mathrm{H}\end{array}$ & 59 & $8 \mathrm{H} 18$ & UNK & 0 & -7.154 & 3.822 & 4.038 & 1.00 & 0.00 \\
\hline $\begin{array}{l}\text { HETATM } \\
\text { C }\end{array}$ & 60 & C63 & UNK & 0 & -8.762 & 6.435 & 4.313 & 1.00 & 0.00 \\
\hline $\begin{array}{l}\text { HETATM } \\
\text { C }\end{array}$ & 61 & C5 & UNK & 0 & -7.645 & 7.440 & 4.606 & 1.00 & 0.00 \\
\hline $\begin{array}{l}\text { HETATM } \\
\mathrm{H}\end{array}$ & 62 & OH2O & UNK & 0 & -7.856 & 8.406 & 4.147 & 1.00 & 0.00 \\
\hline $\begin{array}{l}\text { HETATM } \\
\mathrm{H}\end{array}$ & 63 & $1 \mathrm{H} 20$ & UNK & 0 & -6.693 & 7.083 & 4.213 & 1.00 & 0.00 \\
\hline $\begin{array}{l}\text { HETATM } \\
\mathrm{H}\end{array}$ & 64 & $2 \mathrm{H} 20$ & UNK & 0 & -7.528 & 7.593 & 5.679 & 1.00 & 0.00 \\
\hline $\begin{array}{l}\text { HETATM } \\
\text { C }\end{array}$ & 65 & C66 & UNK & 0 & -10.115 & 6.902 & 4.854 & 1.00 & 0.00 \\
\hline $\begin{array}{l}\text { HETATM } \\
\mathrm{H}\end{array}$ & 66 & $3 \mathrm{H} 20$ & UNK & 0 & -10.412 & 7.848 & 4.402 & 1.00 & 0.00 \\
\hline $\begin{array}{l}\text { HETATM } \\
\mathrm{H}\end{array}$ & 67 & $4 \mathrm{H} 20$ & UNK & 0 & -10.077 & 7.041 & 5.935 & 1.00 & 0.00 \\
\hline $\begin{array}{l}\text { HETATM } \\
\mathrm{H}\end{array}$ & 68 & $5 \mathrm{H} 20$ & UNK & 0 & -10.891 & 6.169 & 4.638 & 1.00 & 0.00 \\
\hline
\end{tabular}

